\title{
Dicer protein levels elevated by mild hyperthermia promote a pro-survival phenotype
}

\author{
Anand S. Devasthanam ${ }^{1}$ and Thomas B. Tomasi ${ }^{1,2,3}$ \\ ${ }^{1}$ Laboratory of Molecular Medicine, Department of Immunology, Roswell Park Cancer Institute, Buffalo, NY 14263, USA \\ ${ }^{2}$ Department of Medicine, State University of New York, School of Medicine and Biomedical Sciences, Buffalo, NY 14214, USA \\ ${ }^{3}$ Department of Microbiology and Immunology, State University of New York, School of Medicine and Biomedical Sciences, \\ Buffalo, NY 14214, USA \\ Correspondence to: Thomas B. Tomasi, email: thomas.tomasi@roswellpark.org \\ Keywords: hyperthermia, dicer, ER stress, elF2a, thermotolerance \\ Received: October 07, $2016 \quad$ Accepted: March 31, $2017 \quad$ Published: April 26, 2017 \\ Copyright: Devasthanam et al. This is an open-access article distributed under the terms of the Creative Commons Attribution \\ License 3.0 (CC BY 3.0), which permits unrestricted use, distribution, and reproduction in any medium, provided the original author \\ and source are credited.
}

\section{ABSTRACT}

Cellular exposure to mild stress $\left(39.5^{\circ} \mathrm{C}-41.5^{\circ} \mathrm{C}\right)$ induces thermotolerance, rendering cells resistant to a subsequent heat shock $\left(>42^{\circ} \mathrm{C}\right)$ insult. We found that mild hyperthermia at $39.5^{\circ} \mathrm{C}$ leads to elevations in dicer, a protein well-known for its role in microRNA processing and for its role in cellular stress responses. However, whether elevated dicer protein levels play a role in sustaining a thermotolerant phenotype has, to our knowledge, not been reported. Here we demonstrate that elevated dicer protein is linked to a thermotolerant phenotype in the cervical carcinoma cell line $\mathrm{HeLa}$ and in murine embryonic fibroblasts (MEF), and demonstrate that dicer plays a role in mediating PKR and eIF2a phosphorylation. These findings suggest that dicer's role in thermotolerance may be to relay signals to key ER stress pathway components. Moreover, utilizing a MEF cell line defective in microRNA processing, we suggest that dicer's influence on PKR and eIF2a phosphorylation is likely distinct from its microRNA processing role. ATF4 and CHOP are well characterized stress response factors proximal to eIF2a. Evidence is presented that elevated dicer protein in thermotolerant cells differentially modulates ATF4 and CHOP levels to promote a pro-survival phenotype. This work contributes new information on dicer's role in cellular stress responses by defining a pro-survival phenotype in heat stress resistant cells which is sustained, at least in part, by elevated dicer protein levels. Our results suggest an ancillary role for dicer in the cellular stress pathways activated by mild hyperthermia that is likely distinct from its role in microRNA processing.

\section{INTRODUCTION}

Mammalian cells respond to hyperthermia by activating adaptive mechanisms designed to preserve cell viability. In response to mild hyperthermic stress, the Heat Shock Response (HSR) and the endoplasmic reticulum (ER) stress response pathways are activated and preserve the integrity of important signaling networks to sustain cell survival under stressful conditions [1-3]. Despite these finely-orchestrated pro-survival mechanisms, cell death ensues as a consequence of persistent cell stress. For instance, hyperthermic stress in the heat shock range $\left(>42^{\circ} \mathrm{C}\right)$ leads to protein denaturation, cell cycle arrest, inhibition of protein and DNA synthesis, as well as disruption of the membrane cytoskeleton with uncoupling of oxidative phosphorylation [4]. In contrast exposing cells to mild hyperthermia $\left(39.5^{\circ} \mathrm{C}-41.5^{\circ} \mathrm{C}\right)$ for extended periods (3-24h) may confer thermotolerance, a transient state of resistance to subsequent hyperthermia treatments [5-8].

The thermotolerant phenotype results from the cumulative outcome of multiple cytoprotective events which occur within a mammalian cell when thermo-tolerance is induced experimentally [9-11]. Recent studies suggest that mild hyperthermia at $40^{\circ} \mathrm{C}$ for 3-6h leads to ER pathway activation [3, 12]. The ER membrane-resident serine/ threonine kinase, PKR-like ER-regulated kinase (PERK), inositol requiring protein $1 \alpha$ (IRE1 $\alpha$ ) and activating 
transcription factor (ATF6) are three stress sensors located in the ER membrane [13]. The IRE1 $\alpha$ and ATF6 arms work synergistically to transactivate ER chaperone genes, including Grp94, Erp72, BiP and CypB, among others [14]. The ER chaperones function cooperatively to sustain the integrity of important signal transduction events, and increase the folding capacity of the ER. PERK phosphorylates the alpha subunit of the eukaryotic translation initiation factor $2 \alpha$ (eIF $2 \alpha$ ) resulting in the global suppression of protein synthesis [15]. Although not fully characterized, the protein kinase R (PKR) - a close relative of PERK [16] - is also known to phosphorylate eIF2 $\alpha$ during ER stress.

An important consequence of eIF $2 \alpha$ phosphorylation is the selective translation of the pro-survival factor, activating transcription factor 4 (ATF4) [17]. ATF4 is a basic leucine zipper (bZIP) protein that can form heterodimers with other bZIP transcription factors, including FOS, JUN and the C/EBP homologous protein (CHOP) [18]. In response to elevated levels of cellular stress, the CHOP protein is stabilized, leading to the elimination of stressed cells via apoptosis [13]. The complete activation of CHOP correlates with the cleavage of ER-associated caspases 12 and 4; phosphorylation of pro-apoptotic kinases ASK1 and JNK; inactivation of the pro-survival factors $\mathrm{Bcl}-2$ and $\mathrm{Bcl}-\mathrm{xL}$; and the activation of the mitochondrial apoptotic pathway [19-22]. These events collectively lead to the cleavage of the terminal caspases, including caspase-3.

Cellular stress responses also reveal a role for dicer. The following studies suggest that stress-induced changes in dicer protein levels may influence stress response pathways, leading to cellular resilience under stressful conditions: Ho et al. demonstrated that the decrease in dicer protein levels observed following hypoxia treatments is causally linked to an increase in HIF-1 [23]; Asada et al. showed that a decrease in dicer protein as observed with serum deprivation - a well-known ER stress inducer - correlates with poor cell survival. Interestingly, this study also showed that the ectopic overexpression of dicer augments cell survival under low serum conditions [24].

In previous work, our group showed [25] that mild heat stress for up to $9 \mathrm{~h}$ at $39.5^{\circ} \mathrm{C}$ induced increases in the protein levels of dicer in human (BT-20, HeLa, JAR, MRC-5, RAJI, SW-13) and murine (B16, SM9) cell lines. We also observed elevated dicer protein levels in primary cultures derived from mouse renal epithelial cells and mouse renal fibroblasts. Whether mild $\left(39.5^{\circ} \mathrm{C}\right)$ hyperthermia treatments also induce thermotolerance, in which dicer plays a role, is currently unclear.

The above observations prompted us to ask: does dicer have a role in influencing stress response pathways during experimentally induced thermotolerance? We hypothesized that the thermotolerant phenotype is sustained, in part, by elevated dicer protein levels. Here we show that mild $\left(39.5^{\circ} \mathrm{C}\right)$ hyperthermia-induced increases in dicer protein levels in HeLa and MEF cells are associated with a thermotolerant phenotype. Also reported here is that the increases in dicer protein levels are linked to eIF $2 \alpha$ phosphorylation in thermotolerant cells. Moreover, we demonstrate that the role of dicer in mediating eIF $2 \alpha$ phosphorylation is likely distinct from its role in microRNA processing. Our results also suggest that the increases in dicer protein levels may play a role in sustaining enhanced ATF4, while curbing CHOP protein levels in thermotolerant cells heading toward heat shock-induced cell death. Collectively, our results support the hypothesis that mild $\left(39.5^{\circ} \mathrm{C}\right)$ hyperthermia-induced increases in dicer protein levels in thermotolerant cells may be driving a pro-survival program, thus favoring a cytoprotective outcome.

\section{RESULTS}

\section{Elevated dicer protein levels observed during mild $\left(39.5^{\circ} \mathrm{C}\right)$ hyperthermia stress are linked to a thermotolerant phenotype in HeLa and murine embryonic fibroblast (MEF) cell lines}

Prior work showed that $6 \mathrm{~h}$ heating at $39.5^{\circ} \mathrm{C}$ increased dicer protein levels in the epithelial cell line HeLa, and in fibroblast cells of human and murine origin [25]. Whether the increase in dicer protein levels observed at $6 \mathrm{~h}$ of heating at $39.5^{\circ} \mathrm{C}$ is associated with a thermotolerant phenotype is currently unclear. In addition, whether dicer protein levels remain elevated with extended periods of heating at $39.5^{\circ} \mathrm{C}$ has not, to our knowledge, been determined.

Bettaieb and colleagues have shown that heating HeLa cells for $3 \mathrm{~h}$ or $6 \mathrm{~h}$ at $40^{\circ} \mathrm{C}$ induces a thermotolerant phenotype [7]. This prompted us to ask: are HeLa and $\mathrm{MEF}$ cells pretreated at $39.5^{\circ} \mathrm{C}$ for $6 \mathrm{~h}$ better able to survive a heat shock $\left(43^{\circ} \mathrm{C}\right)$ treatment delivered over a period of $2 \mathrm{~h}$ ? In addition, to determine the effect of more extended periods of heating on dicer protein levels we incubated cells at $39.5^{\circ} \mathrm{C}$ for $16 \mathrm{~h}$. Our results showed that heating HeLa cells for $6 \mathrm{~h}$ and $16 \mathrm{~h}$ leads to 2.1 -fold and 2.5 -fold increase in dicer protein levels when averaged over three independent experiments (Figure 1A and 1B, lanes 1-3). Under identical experimental conditions, the fold changes in dicer protein levels, in MEFs were 1.6-fold and 2.4-fold respectively (Figure 1C and 1D, lanes 1-3).

To gain insight into the biological relevance of elevated dicer protein levels observed in cells treated with mild hyperthermia at $39.5^{\circ} \mathrm{C}$, we conducted knockdown studies in HeLa and MEF cell lines. We first verified that dicer knockdown via siRNA leads to a significant reduction in the steady state levels of the dicer protein in HeLa cells without resulting in cell death. We heated control-transfected as well as dicer knockdown HeLa and $\mathrm{MEF}$ cells at $39.5^{\circ} \mathrm{C}$ for $6 \mathrm{~h}$ and $16 \mathrm{~h}$ and then challenged the heated cells with a cytotoxic heat shock treatment. To ensure that heat shock treatments induced cell death, a positive control group that received heat shock treatments alone was included. We conducted MTT cell viability 
assays and determined the proportion of viable cells under each treatment condition. Our results suggest that HeLa and MEF cells treated under mild hyperthermia at $39.5^{\circ} \mathrm{C}$ for $6 \mathrm{~h}$ or $16 \mathrm{~h}$ become thermotolerant, as evidenced by a significant increase in the proportion of cells surviving a heat shock challenge (Figure $1 \mathrm{E}$ and $1 \mathrm{~F}$ ). These results are consistent with previous reports [7] suggesting that treating cells with mild hyperthermia stress is a method of inducing thermotolerance in an experimental setting. The results from the dicer knockdown studies suggest that the elevations in dicer protein levels are linked to a thermotolerant phenotype, shown by the significant decrease in the proportion of dicer knockdown HeLa and MEF cells surviving a heat shock challenge (Figure 1E and $1 \mathrm{~F}$ ). It is important to note that dicer knockdown in

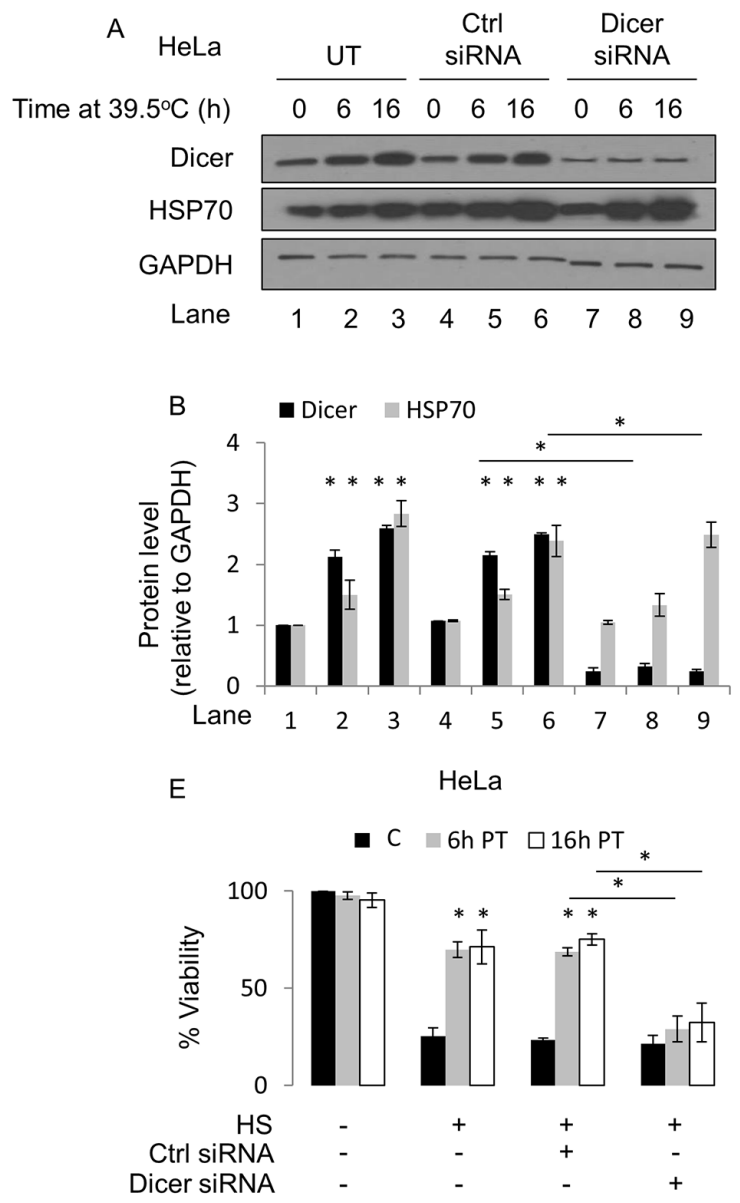

HeLa and MEF cells heated at $39.5^{\circ} \mathrm{C}$ for $6 \mathrm{~h}$ and $16 \mathrm{~h}$ did not significantly alter the induction of HSP70 protein levels. When stabilized by thermal stress, HSP70 plays an important role in conferring a thermotolerant phenotype [28]. As an initial step in determining the mechanism by which dicer may potentially stabilize HSP70 protein levels during hyperthermia stress, we asked whether dicer is required for hyperthermia-induced increases in HSP70 protein levels. To this end, we heated wildtype (WT) and dicer deficient (DCR ${ }^{-/}$) HCT116 cells at mild hyperthermia for $16 \mathrm{~h}$ and found that HSP70 protein levels increased in WT as well as in dicer deficient cell lines (Figure 2). These results suggest that the role of dicer in mild hyperthermia-induced thermotolerance likely does not involve the modulation of HSP70 protein levels.

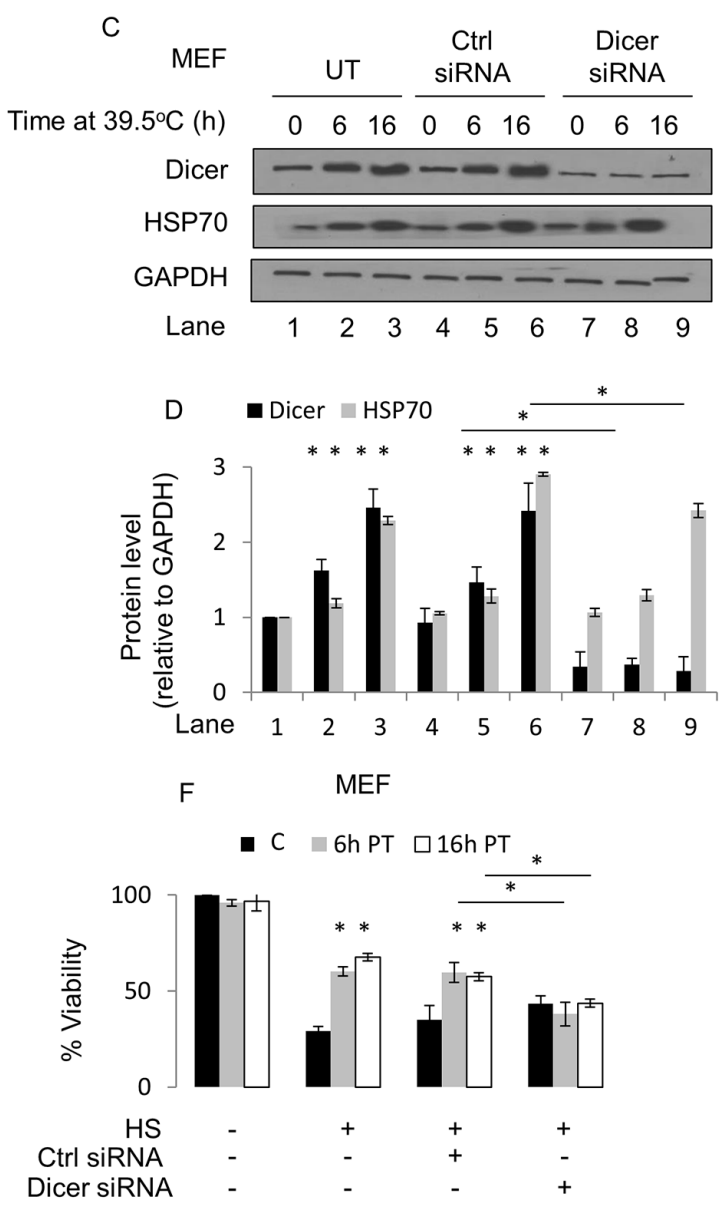

Figure 1: Elevated dicer protein levels are linked to a thermotolerant phenotype in HeLa and murine embryonic fibroblast (MEF) cell lines. (A) Western blot analysis of dicer, HSP70 and GAPDH protein levels in HeLa cells at $39.5^{\circ} \mathrm{C}$ for $0 \mathrm{~h}, 6 \mathrm{~h}$ and 16h. Experiments were conducted under untransfected (UT), control-transfected (Ctrl siRNA) or dicer knockdown (dicer siRNA) conditions. (B) Protein band intensities in (A) were first normalized to the GAPDH band intensities corresponding to the specific protein and further normalized to the $0 \mathrm{~h}$ time point in the untransfected group within each biological replicate. (C) Western blot analysis of experiments in MEF cells conducted as described in (A). (D) Band intensities in (C) analyzed as described in (B). (E) MTT cell viability assays in control $\left(37^{\circ} \mathrm{C}\right) \mathrm{HeLa}$ cells heated at $43^{\circ} \mathrm{C}(\mathbf{C})$; mild hyperthermia (6h at $\left.39.5^{\circ} \mathrm{C}\right)$ pretreated (PT) cells subsequently heated at $43^{\circ} \mathrm{C}(6 \mathrm{~h} \mathrm{PT})$; and mild hyperthermia $\left(16 \mathrm{~h}\right.$ at $\left.39.5^{\circ} \mathrm{C}\right)$ pretreated cells subsequently heated at $43^{\circ} \mathrm{C}(16 \mathrm{~h} \mathrm{PT})$. (F) MTT cell viability assays in MEF cells conducted as described in (E). The representative western blot images for GAPDH correspond to the western blot image for dicer in this figure. Values shown are mean \pm SEM. $n=3, * p<0.05$. 
Elevated dicer protein levels observed during mild $\left(39.5^{\circ} \mathrm{C}\right)$ hyperthermia-induced thermotolerance are linked to PKR and eIF2 $\alpha$ phosphorylation in HeLa cells

To gain further insight into the role of dicer in thermotolerance, we performed studies to address the potential role of dicer in pathways relevant to the ER stress response. Previous studies showing that mild hyperthermia at $40^{\circ} \mathrm{C}$ is associated with the phosphorylation of eukaryotic Initiation Factor 2 alpha-subunit (eIF2 $\alpha$ ) on Serine $51[3,12]$ prompted us to ask: are elevated dicer protein levels causally linked to the activation of key components in the ER stress pathway?

Under control $\left(37^{\circ} \mathrm{C}\right)$ conditions, there were no detectable changes in phosphorylated PKR (Thr451) and eIF2 $\alpha$ (Ser51) (Figure 3A, lanes 1-3, and Figure 3B). As a positive control, we utilized TNF- $\alpha$ which is known to induce phosphorylation of eIF2 $\alpha$ via PKR [26] (Figure $3 \mathrm{~A}$, lane 4, and Figure 3B). Additionally, at $39.5^{\circ} \mathrm{C}$ we observed significant increases in phosphorylated PKR as well as eIF2 $\alpha$ at $6 \mathrm{~h}$ and $16 \mathrm{~h}$ time points (Figure 3A, lanes 5-7, and Figure 3B). Interestingly, the increases observed in dicer protein levels appeared to coincide with the phosphorylation status of PKR as well as eIF $2 \alpha$. This observation was consistent in cells transfected with a control siRNA (Figure 3A, lanes 9-11, and Figure 3B). Potentially important is the observation that dicer knockdown led to a significant reduction in the phosphorylation of eIF $2 \alpha$ as well as PKR in cells heated at $39.5^{\circ} \mathrm{C}$ for $6 \mathrm{~h}$ and $16 \mathrm{~h}$ (Figure $3 \mathrm{~A}$, lanes $13-15$, and Figure 3B).
EIF2 $\alpha$ can be phosphorylated by four kinases: PKR, HRI, PEK and GCN2 [27]. This prompted us to ask: does experimentally induced thermotolerance lead to the activation of eIF2 $\alpha$ via a PKR-dependent mechanism; and are the observed increases in dicer protein levels causally linked to the phosphorylation of eIF $2 \alpha$ ? To address this question, we analyzed the protein levels of dicer as well as phosphorylated PKR and eIF $2 \alpha$ in cells at $39.5^{\circ} \mathrm{C}$ that were pretreated with a small molecule inhibitor of PKR. Our results showed that PKR inhibition significantly suppressed the phosphorylation of PKR and eIF $2 \alpha$ despite the increases in dicer protein levels (Figure 3A, lanes 1819, and Figure 3B). We also verified that the PKR inhibitor alone $(250 \mathrm{nM}$ for $16 \mathrm{~h})$ under control $\left(37^{\circ} \mathrm{C}\right)$ conditions did not significantly affect dicer protein levels (data not shown).

Taken together, these results suggest that PKR and eIF $2 \alpha$ phosphorylation are observed during experimentally induced thermotolerance in HeLa cells, and that PKR may be mediating eIF $2 \alpha$ phosphorylation in thermotolerant cells. Moreover, our results support the hypothesis that the elevations in dicer protein levels are linked to the phosphorylation of PKR and eIF $2 \alpha$ during mild $\left(39.5^{\circ} \mathrm{C}\right)$ hyperthermia-induced thermotolerance.

\section{The role of dicer in regulating $\mathrm{PKR}$ and eIF $2 \alpha$ phosphorylation during mild $\left(39.5^{\circ} \mathrm{C}\right)$ hyperthermia-induced thermotolerance is likely distinct from its role in microRNA processing}

To obtain further mechanistic insight into whether experimentally induced thermotolerance influences dicer
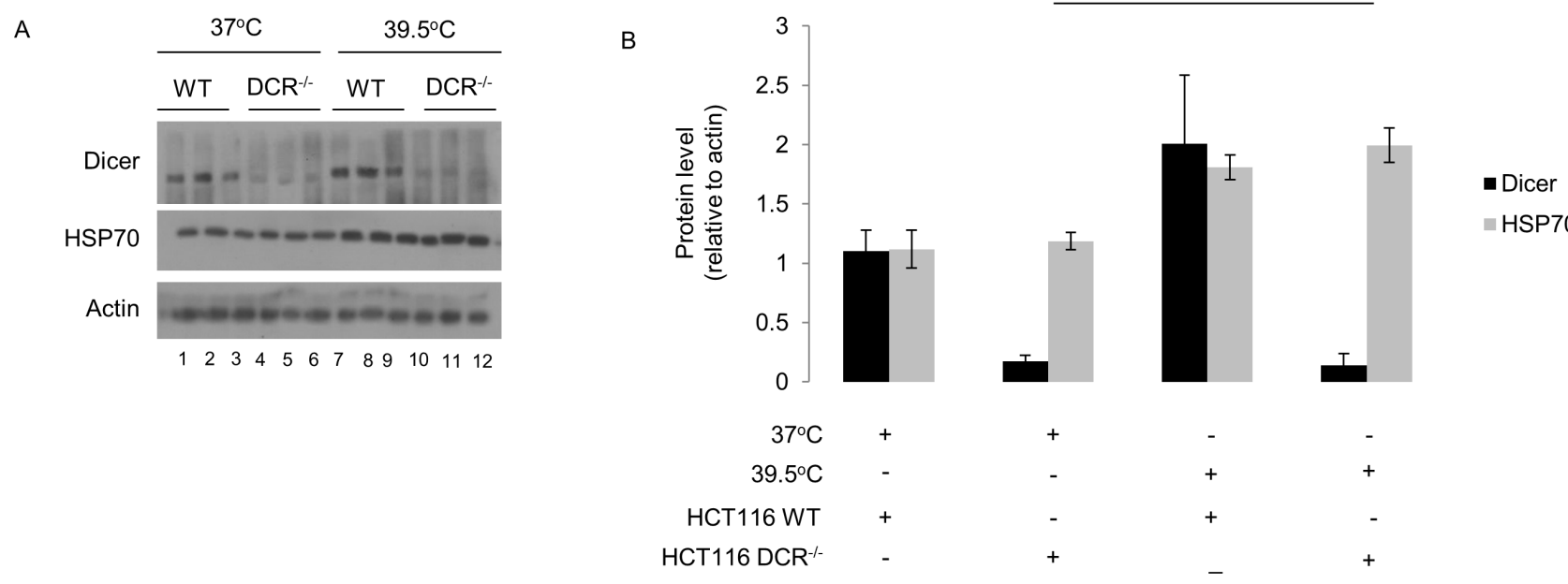

-HSP70

Figure 2: Elevated dicer protein levels observed during mild $\left(39.5^{\circ} \mathrm{C}\right)$ hyperthermia-induced thermotolerance are not linked to HSP70 protein levels. (A) Western blot analysis of HSP70 protein levels in wildtype (WT) and dicer deficient (DCR-/-) HCT116 cells at mild hyperthermia $\left(39.5^{\circ} \mathrm{C}\right)$ for $16 \mathrm{~h}$. (B) Protein band intensities in (A) were first normalized to the actin band intensities corresponding to the specific protein and further normalized to the first experimental replicate in control (lane 1) and mild hyperthermia (lane 7) samples within each biological replicate. The representative western blot images for Actin correspond to the western blot image for dicer in this figure. Values shown are mean \pm SEM. $p<0.05$. 
activity, we conducted a dicer activity assay with HeLa cells treated with mild hyperthermia for $6 \mathrm{~h}$ and $16 \mathrm{~h}$.

Dicer cleaves pre-microRNAs ( 70nt) via its RNase III domains to form mature microRNAs ( 22nt). To determine whether the elevations in dicer protein levels observed during experimentally induced thermotolerance correlate with dicer activity, we conducted an in vitro dicer activity assay designed to measure the cleavage of a radiolabelled pre-microRNA substrate (88nt) to a mature microRNA product (22nt). Pre-miR-124a was chosen as the substrate for this assay because it is not generated endogenously in the cell types used in this study.

Our results from the dicer activity assay suggest that there are no significant differences in the band intensities corresponding to the $22 \mathrm{nt}$ product in samples from the $6 \mathrm{~h}$ and $16 \mathrm{~h}$ heating groups (Figure $4 \mathrm{~A}$ and $4 \mathrm{~B}$ ). To ensure that the activity assay was specific to dicer, we analyzed the differences in the band intensities corresponding to the mature microRNA product between whole cell lysates derived from wildtype (WT) and dicer LOF MEFs (Figure $4 \mathrm{~A}$ and $4 \mathrm{C}$ ). The expression of dicer was confirmed in both WT and dicer LOF MEF lysates (data not shown). Reactions contained 20 micrograms of total protein derived from mild $\left(39.5^{\circ} \mathrm{C}\right)$ hyperthermia treated HeLa cells. Whole cell protein lysates containing 10, 20 and 30 micrograms of total protein derived from HeLa cells were included to show that the amount of protein in the reaction did not saturate the assay (Figure 4A and 4D). Taken together, we conclude that the elevations in dicer protein levels observed during experimentally induced thermotolerance do not lead to enhanced dicer activity.

The data also support the idea that increases in dicer protein levels alone are sufficient to mediate PKR and eIF $2 \alpha$ phosphorylation in thermotolerant cells. To

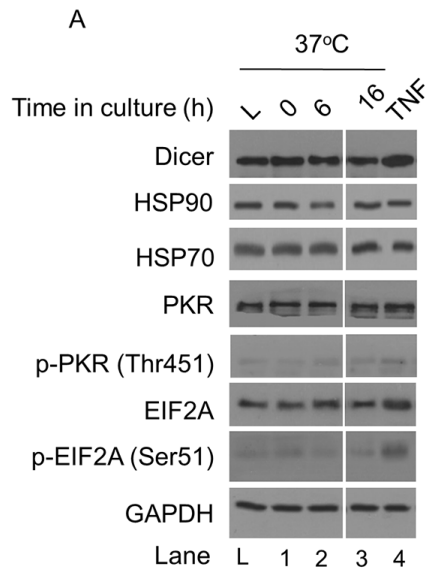

B

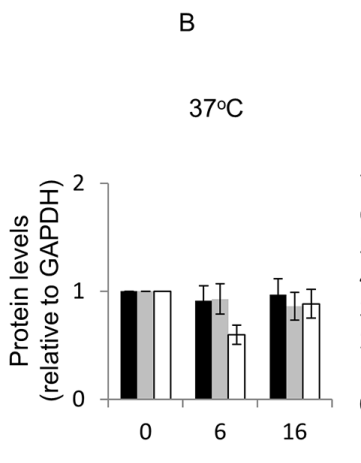

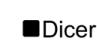

Dicer

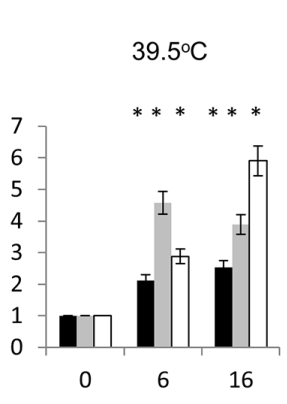

$\mathrm{p}-\mathrm{PKR} / \mathrm{PKR}$
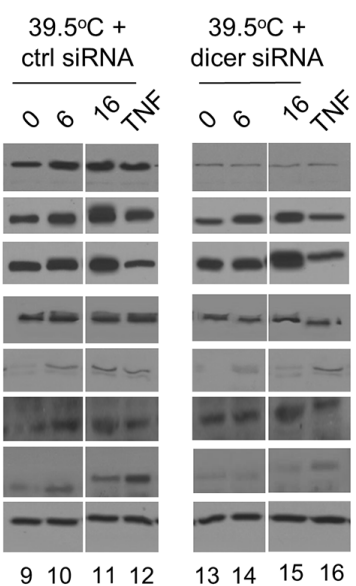

$39.5^{\circ} \mathrm{C}+$

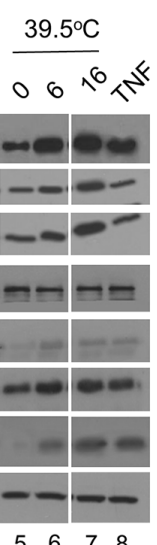

9101112
PKR inhibitor

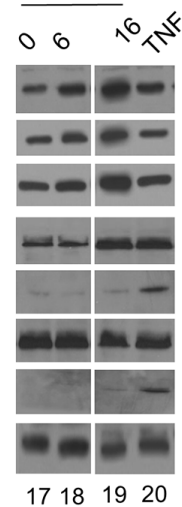

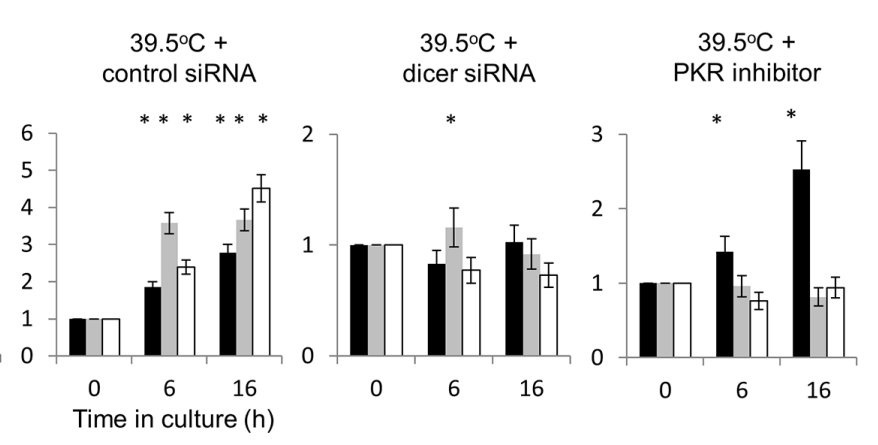

Figure 3: Elevated dicer protein levels observed during mild $\left(39.5^{\circ} \mathrm{C}\right)$ hyperthermia-induced thermotolerance are linked to PKR and eIF2 $\alpha$ phosphorylation in HeLa cells. (A) Western blot analysis of dicer, phosphorylated and total PKR and eIF $2 \alpha$ at $37^{\circ} \mathrm{C}$ and at $39.5^{\circ} \mathrm{C}$ in the presence of control or dicer siRNA. Mild hyperthermia treatments were initiated $48 \mathrm{~h}$ post-transfection. TNF-alpha (10 ng/ml for $2 \mathrm{~h}$ ) was used as the positive control for phosphorylated PKR and eIF2 $\alpha$. A PKR inhibitor (250 nM) was added $1 \mathrm{~h}$ before mild hyperthermia treatments were initiated. The lane ' $\mathrm{L}$ ' indicates a commercial source of HeLa cell lysate that was used as a comparator to confirm that cells used in our experiments did not have detectable levels of active PKR in the absence of cell stress. PKR inhibitor was added to samples heated for 0h, 6h and 16h (i.e. lanes 17, 18 and 19). (B) Protein band intensities in (A) were first normalized to the GAPDH band intensities corresponding to that specific protein and further normalized to the $0 \mathrm{~h}$ time point in the respective experimental group. Breaks in western blot images were created to juxtapose time points pertinent to the experimental question. The ratios of phosphorylated to total proteins are graphed. The representative western blot images for GAPDH correspond to the western blot image for dicer this figure. Values shown are mean \pm SEM. $n=3,{ }^{*} \mathrm{p}<0.05$. 
test this, we asked whether elevated levels of the dicer protein, rather than its ability to process microRNAs, might have a greater impact on mediating PKR and eIF2 $\alpha$ phosphorylation in thermotolerant cells. We analyzed the phosphorylation of PKR and eIF $2 \alpha$ in WT and in dicer LOF MEF cell lines heated at $39.5^{\circ} \mathrm{C}$ for $16 \mathrm{~h}$. In initial studies, we found that $16 \mathrm{~h}$ of heating led to greater increases in dicer protein levels compared to $6 \mathrm{~h}$ of heating in MEF cells (Figure 1). Therefore, we focused on the $16 \mathrm{~h}$ time point to explore a potential causal link between elevations in dicer protein levels and phosphorylation events on PKR and eIF $2 \alpha$.

Under control $\left(37^{\circ} \mathrm{C}\right)$ conditions, there were no significant differences in dicer protein levels between WT and dicer LOF cells (Figure 5A, lanes 1-6, and Figure $5 \mathrm{~B})$, and also no significant differences in phosphorylated eIF $2 \alpha$ levels between WT and dicer LOF cells. Consistent with our results in HeLa cells, WT MEFs that were heated for $16 \mathrm{~h}$ at $39.5^{\circ} \mathrm{C}$ showed significant increases in dicer, phosphorylated PKR and phosphorylated
eIF $2 \alpha$. Consistent with results in WT MEFs, dicer LOF MEFs that were heated for $16 \mathrm{~h}$ at $39.5^{\circ} \mathrm{C}$ also showed significant increases in dicer, phosphorylated PKR and phosphorylated eIF2 $\alpha$ (Figure 5A, lanes 7-12, and Figure $5 B)$. These results suggest that elevated dicer protein observed during experimentally induced thermotolerance is associated with increases in phosphorylated PKR and phosphorylated eIF2 $\alpha$ in MEFs expressing functionally defective dicer protein.

To determine whether elevated levels of the dicer protein itself could sustain PKR and eIF $2 \alpha$ phosphorylation in thermotolerant cells, dicer protein levels were suppressed in dicer LOF MEFs by transfecting cells with a dicer-targeting siRNA. Dicer protein levels and phosphorylated PKR and eIF2 $\alpha$ in cells treated under mild $\left(39.5^{\circ} \mathrm{C}\right)$ hyperthermia stress for $16 \mathrm{~h}$ were then analyzed. Our results suggest that, while PKR and eIF2 $\alpha$ are phosphorylated in heated WT and LOF cells transfected with a control siRNA (Figure 5A, lanes 13-18, and Figure $5 \mathrm{C})$, these phosphorylation events were largely abrogated
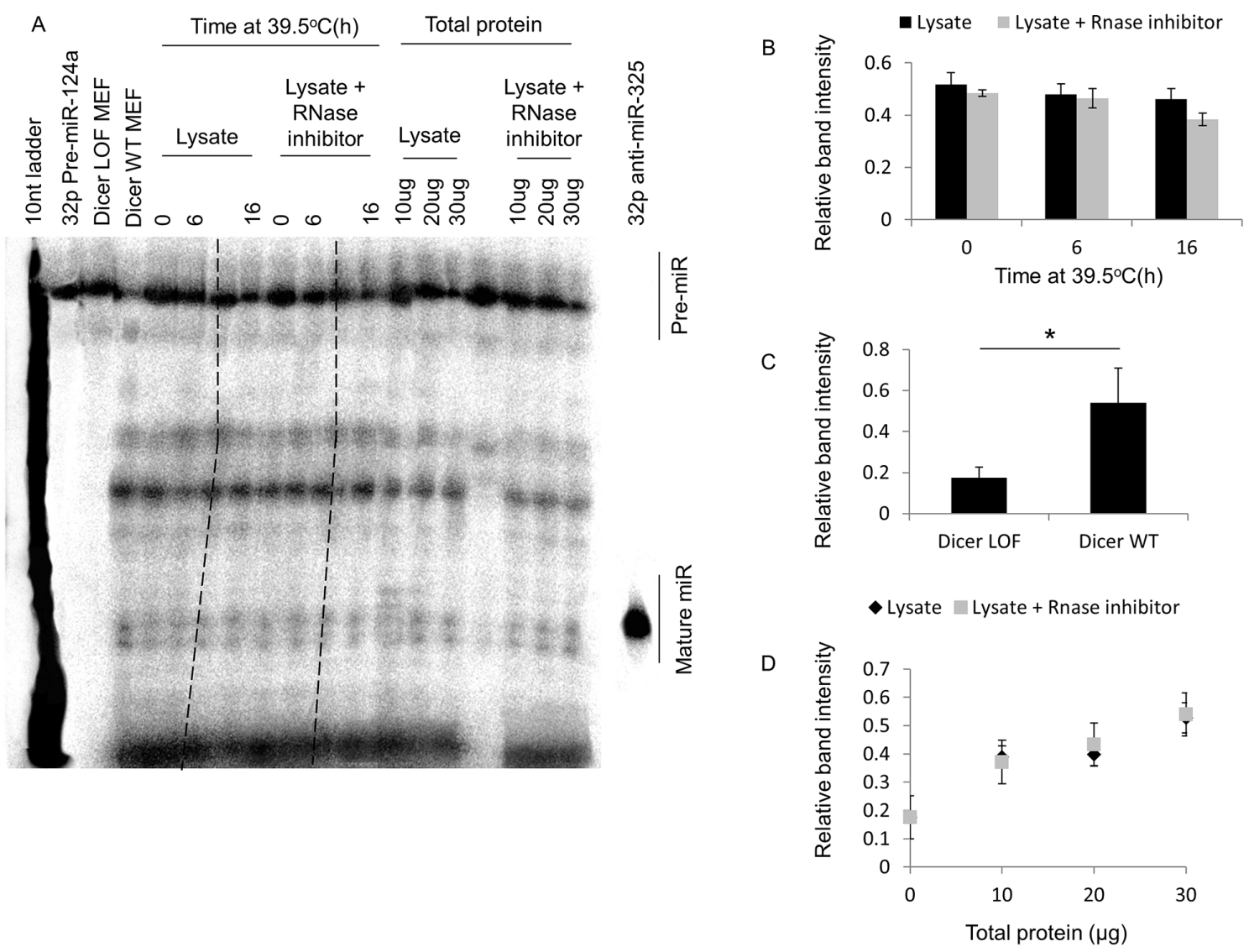

Figure 4: Mild hyperthermia $\left(39.5^{\circ} \mathrm{C}\right)$ stress-induced thermotolerance does not significantly alter dicer activity in HeLa cells. (A) Urea PAGE analysis of radiolabeled pre-microRNA-124a and mature microRNA-124a in HeLa cells at $39.5^{\circ} \mathrm{C}$ for $0 \mathrm{~h}, 6 \mathrm{~h}$ and 16h. Gel lanes excluded from analysis are crossed out with broken lines. (B) The ratio of the band intensities of the mature microRNA to that of the pre-microRNA (i.e. relative 22nt mature MicroRNA band intensity) in lanes containing cell lysate alone, or cell lysate supplemented with RNase inhibitor. (C) Relative band intensities of lanes containing lysates from dicer LOF and wildtype (WT) MEFs. (D) Relative band intensities of lanes containing 10, 20 and 30 ug of total protein from lysate alone, or lysate supplemented with RNase inhibitor. Lanes excluded from the analysis are marked with broken lines. Values shown are mean \pm SEM. $n=3 ;{ }^{*} \mathrm{p}<0.05$. 
in dicer knockdown cells (Figure 5A, lanes 19-24, and Figure 5C). Taken together, the results support the concept that the elevations in dicer protein levels observed during mild $\left(39.5^{\circ} \mathrm{C}\right)$ hyperthermia-induced thermotolerance are sufficient to sustain phosphorylation events on PKR and eIF $2 \alpha$, and influence the PKR and eIF2 $\alpha$ phosphorylation in thermotolerant cells via mechanisms that are likely distinct from its role in microRNA processing.

\section{Elevated dicer protein levels observed during mild $\left(39.5^{\circ} \mathrm{C}\right)$ hyperthermia-induced thermotolerance influence ATF4 and CHOP protein levels in HeLa and MEF cells}

Stress-induced increases in ATF4 protein levels lead to the activation of ATF3, CHOP, HO-1, RANKL and VEGF - factors that play important roles in stress remediation pathways collectively referred to as the integrated stress response [49]. It is now recognized that elevated ATF4 protein levels are primarily associated with a pro-survival outcome. In contrast, stress-induced increases in CHOP protein levels are associated with a pro-apoptotic outcome, as evidenced by a direct correlation between elevated CHOP protein levels and the activation of GADD53, TRIB3, IL6, PUMA and BIM and terminal caspases, including caspase-3 [50, 51]. Since thermotolerance is thought to be a form of stress adaptation, are the elevations in dicer protein levels influencing ATF4 and CHOP protein levels?

To address this question, HeLa and MEF controltransfected and dicer knockdown cells were heated for $6 \mathrm{~h}$ and $16 \mathrm{~h}$ at $39.5^{\circ} \mathrm{C}$ and protein levels of ATF4 and CHOP

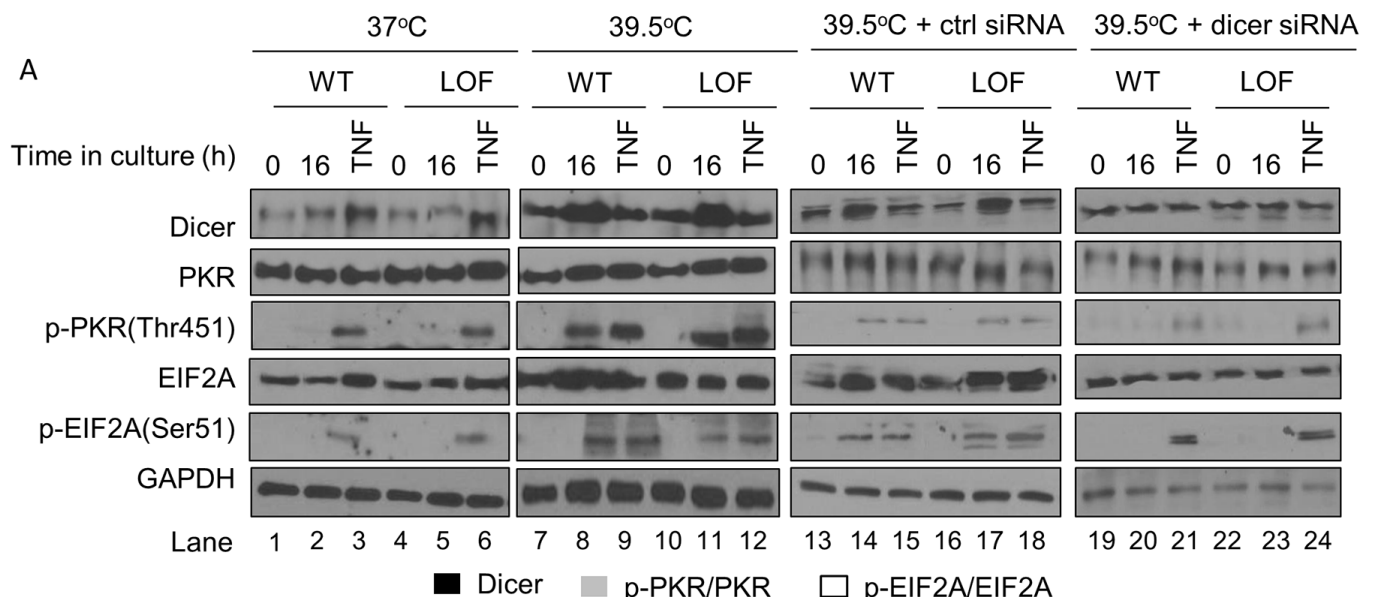

B
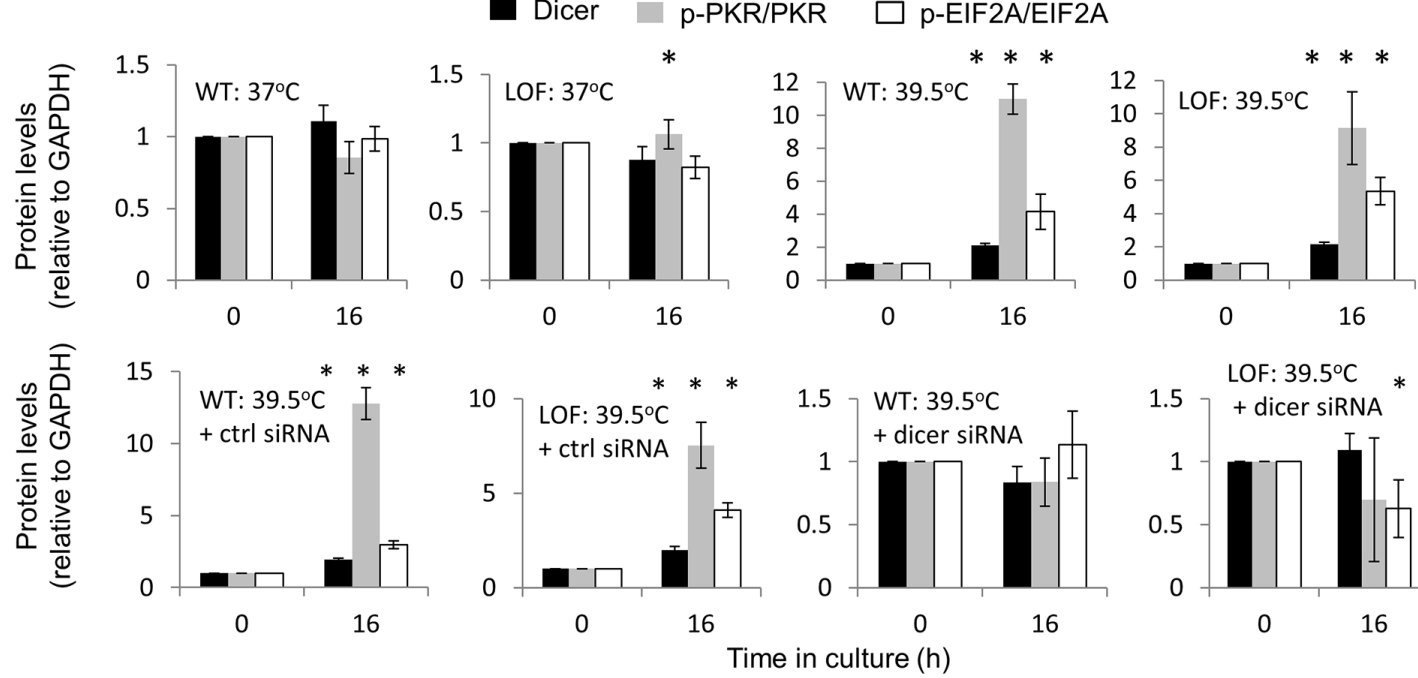

Figure 5: The role of dicer in influencing PKR and eIF2 $\alpha$ phosphorylation during mild $\left(39.5^{\circ} \mathrm{C}\right) \mathrm{hyperthermia-}^{-}$ induced thermotolerance is likely distinct from its role in microRNA processing. (A) Western blot analysis of dicer, total and phosphorylated PKR, total and phosphorylated eIF2 $\alpha$ and GAPDH in WT and dicer LOF MEFs at $0 \mathrm{~h}$ and $16 \mathrm{~h}$ at $39.5^{\circ} \mathrm{C}$ under untransfected (lanes 1-12), control-transfected (lanes 13-18), and dicer knockdown (lanes 19-24) conditions. (B) Protein band intensities in (A: lanes 1-12) were first normalized to GAPDH band intensities corresponding to that specific protein and further normalized to the $0 \mathrm{~h}$ time points in the respective experimental group. (C) Band intensities in (A: lanes 13-24) were analyzed by the same method described in (B). The ratios of phosphorylated to total proteins in $(\mathbf{A})$ are graphed in $(\mathbf{B})$ and $(\mathbf{C})$. The representative western blot images for GAPDH correspond to the western blot image for dicer this figure. Values shown are mean \pm SEM. $n=3,{ }^{*} \mathrm{p}<0.05$. 
analyzed. We observed increases in ATF4 protein levels in HeLa cells heated at $39.5^{\circ} \mathrm{C}$ for $6 \mathrm{~h}$ and $16 \mathrm{~h}$ (Figure 6A, lanes 1-6, and Figure 6B). An analysis of $\mathrm{CHOP}$ protein levels in HeLa cells showed increases in CHOP protein at $6 \mathrm{~h}$ of heating at $39.5^{\circ} \mathrm{C}$, which declined significantly by the $16 \mathrm{~h}$ time point (Figure $6 \mathrm{~A}$, lanes 1-6, and Figure 6C). The increases in ATF4 and CHOP protein levels were largely suppressed in dicer knockdown HeLa cells (Figure 6A, lanes 7-9, and Figure 6B and 6C). Also, as with the observations in HeLa cells, CHOP protein levels at $16 \mathrm{~h}$ of heating at $39.5^{\circ} \mathrm{C}$ were significantly lower than those at the 6h time point in MEF cells (Figure 6D, lanes 1-6, and Figure 6F). Importantly, these increases were largely suppressed in dicer knockdown MEF cells (Figure 6D, lanes 7-9, and Figure $6 \mathrm{E}$ and $6 \mathrm{~F}$ ). Taken together, our results support the notion that elevations in dicer protein levels observed during mild $\left(39.5^{\circ} \mathrm{C}\right)$ hyperthermia- induced thermotolerance influence ATF4 and CHOP protein levels.

\section{Elevated dicer protein levels observed during mild $\left(39.5^{\circ} \mathrm{C}\right)$ hyperthermia-induced thermotolerance is associated with a pro-survival phenotype in HeLa and MEF cells}

The question of whether a potential link exists between elevated dicer protein levels and ATF4 and/or CHOP protein levels in thermotolerant cells challenged with persistent cell stress was addressed by carrying out time course experiments in thermotolerant HeLa and MEF cells with varying time points of heat shock at $43^{\circ} \mathrm{C}$.

The results suggest that experimentally induced thermotolerance (i.e. $39.5^{\circ} \mathrm{C}, 16 \mathrm{~h}$ ) restructures ATF4 and $\mathrm{CHOP}$ induction patterns in cells subsequently challenged

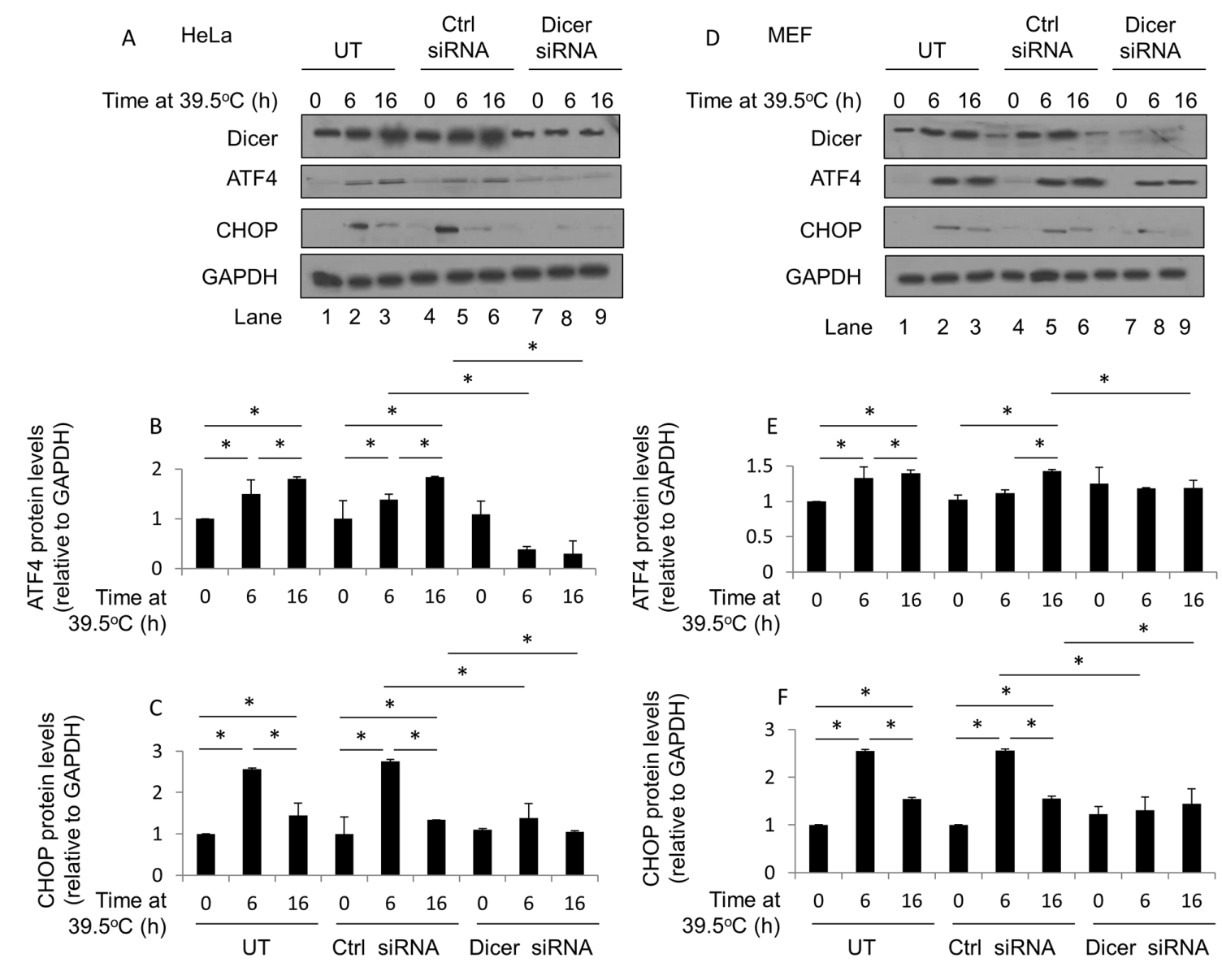

Figure 6: Elevated dicer protein levels observed during mild $\left(39.5^{\circ} \mathrm{C}\right)$ hyperthermia-induced thermotolerance influence ATF4 and CHOP protein levels in HeLa and MEF cells. (A) Western blot analysis of dicer, ATF4, CHOP and GAPDH protein levels in $\mathrm{HeLa}$ cells at $39.5^{\circ} \mathrm{C}$ for $0 \mathrm{~h}, 6 \mathrm{~h}$ and $16 \mathrm{~h}$ under untransfected (UT), control-transfected (Ctrl siRNA), and dicer knockdown (dicer siRNA) conditions. (B) ATF4 band intensities in (A) were first normalized to GAPDH band intensities corresponding to ATF4 (not shown) and further normalized to the $0 \mathrm{~h}$ value in the untransfected group. (C) CHOP band intensities in (A) were first normalized to GAPDH band intensities corresponding to CHOP (not shown) and further normalized to the $0 \mathrm{~h}$ value in the untransfected group. (D) Western blot analysis as described in (A) conducted in MEF cells (E). ATF4 band intensity analysis as described in (B) conducted in MEF cells (F). CHOP band intensity analysis as described in $(\mathrm{C})$ conducted in MEF cells. The representative western blot images for GAPDH correspond to the western blot image for dicer this figure. Values shown are mean \pm SEM. $n=3,{ }^{*} \mathrm{p}<0.05$. 
with a heat shock insult. Specifically, heat shock results in increased ATF4 (Figure 7A and 7B), compare broken and dotted lines) and suppressed CHOP (Figure 7A and $7 \mathrm{C}$, compare broken and dotted lines) in thermotolerant HeLa cells. While there were differences in the patterns of induction in MEF cells of ATF4 (Figure 7D and Figure 7E) and CHOP (Figure 7D and Figure 7F), results in MEF cells were consistent with those observed in HeLa cells.

Our data also suggest that in HeLa cells under thermotolerance-inducing conditions (i.e. $39.5^{\circ} \mathrm{C}, 16 \mathrm{~h}$ ), dicer knockdown appeared to constrain increases in ATF4 protein levels (Figure 7A and 7B), compare broken and dotted lines). Under similar experimental conditions, dicer knockdown was associated with increases in $\mathrm{CHOP}$ protein levels (Figure 7A and Figure 7C, compare broken
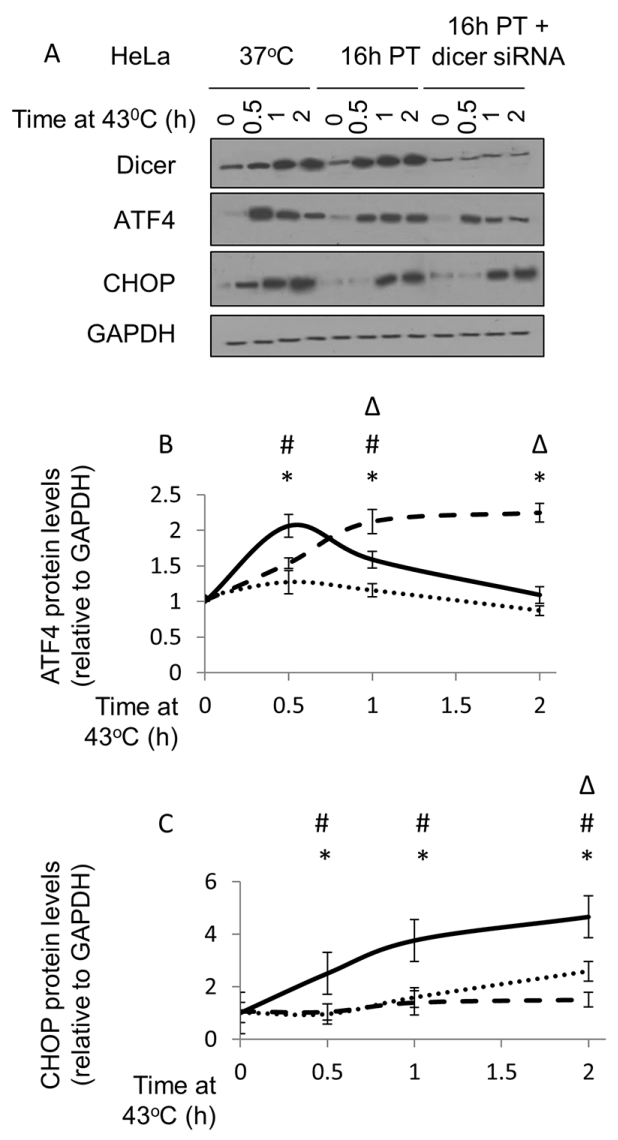

and dotted lines). Results in MEF cells were consistent with those observed in HeLa cells (Figure 7D-7F).

Collectively, these results suggest that the prosurvival phenotype (i.e. increased ATF4, suppressed CHOP) associated with experimentally induced thermotolerance is reversed (i.e. decreased ATF4, increased CHOP) in dicer knockdown cells.

Since dicer knockdown diminished the increases in the pro-survival factor ATF4, and coincided with increases in the pro-apoptotic factor CHOP in thermotolerant cells challenged with a heat shock insult, we believe that the elevated dicer protein levels observed during mild $\left(39.5^{\circ} \mathrm{C}\right)$ hyperthermia-induced thermotolerance play a role in establishing a pro-survival phenotype. Therefore, we reason that the elevated dicer protein levels observed during mild $\left(39.5^{\circ} \mathrm{C}\right)$ hyperthermia-induced thermotolerance play a
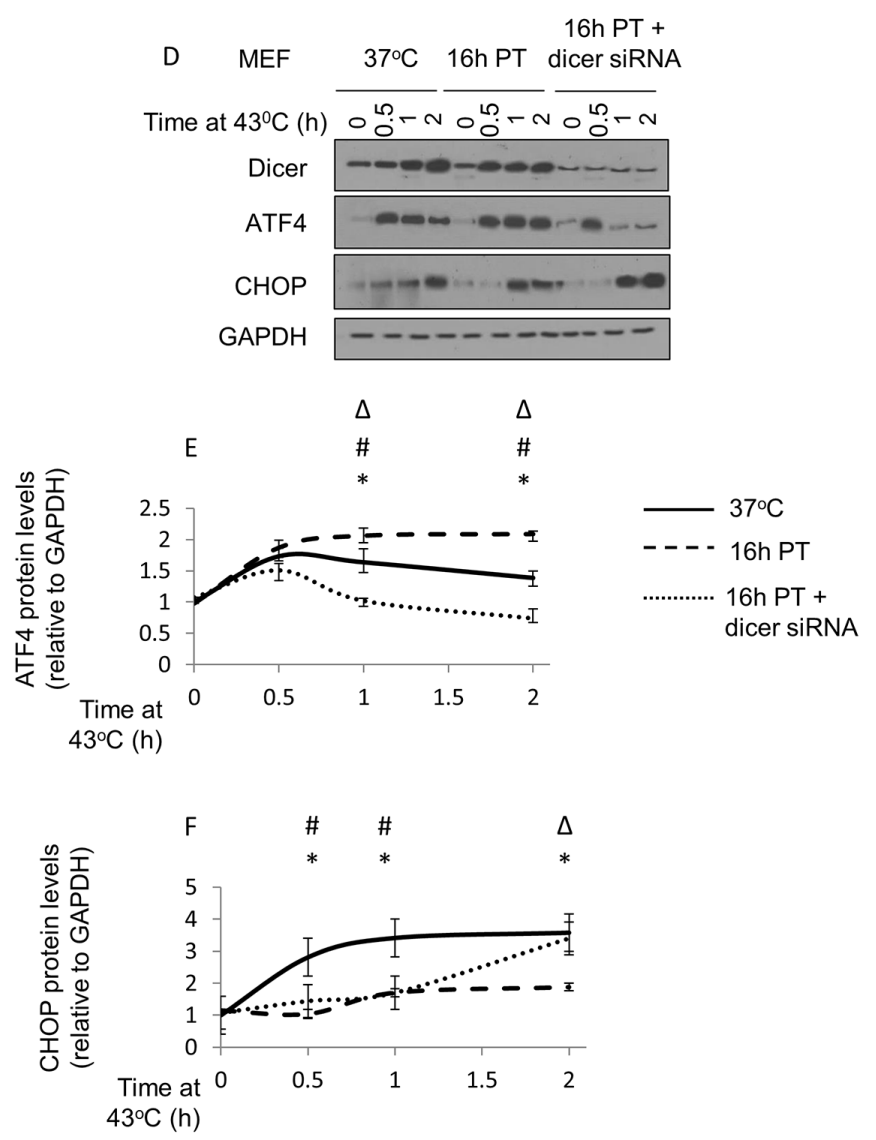

Figure 7: Elevated dicer protein levels observed during mild $\left(39.5^{\circ} \mathrm{C}\right)$ hyperthermia-induced thermotolerance is associated with a pro-survival phenotype in HeLa and MEF cells. (A) Western blot analysis of dicer, ATF4, CHOP and GAPDH protein levels in control $\left(37^{\circ} \mathrm{C}\right)$, mild hyperthermia $\left(39.5^{\circ} \mathrm{C}\right)$ pretreated $(16 \mathrm{~h} \mathrm{PT})$, and mild hyperthermia pretreated dicer knockdown $(16 \mathrm{~h}$ $\mathrm{PT}+$ dicer siRNA) HeLa cells challenged with a heat shock $\left(43^{\circ} \mathrm{C}\right)$ insult for $0,0.5,1$ and $2 \mathrm{~h}$. (B) ATF4 band intensities in (A) were first normalized to GAPDH band intensities corresponding to ATF4 (not shown) and further normalized to the $0 \mathrm{~h}$ time point in the control $\left(37^{\circ} \mathrm{C}\right.$ ) group. Statistically significant $(\mathrm{p}<0.05)$ differences between control and $16 \mathrm{hPT}(*)$; control and $16 \mathrm{hPT}+$ dicer siRNA (\#); and $16 \mathrm{hPT}$ and 16h PT + dicer siRNA $(\Delta)$ are displayed. (C) CHOP band intensities in (A) were first normalized to GAPDH band intensities corresponding to CHOP (not shown) and analyzed as described in (B). (D) Western blot analysis as described in (A) conducted in MEF cells. (E) ATF4 band intensity analysis as described in (B) conducted in MEF cells. (F) CHOP band intensity analysis as described in (C) conducted in MEF cells. The representative western blot images for GAPDH correspond to the western blot image for dicer in this figure. Values shown are mean \pm SEM. $\mathrm{n}=3,{ }^{*} \mathrm{p}<0.05\left(37^{\circ} \mathrm{C}\right.$ v/s $\left.16 \mathrm{hPT}\right), \# \mathrm{p}<0.05\left(37^{\circ} \mathrm{C} \mathrm{v} / \mathrm{s} 16 \mathrm{hPT}+\right.$ dicer siRNA $), \Delta \mathrm{p}<0.05(16 \mathrm{hPT} \mathrm{v} / \mathrm{s} 16 \mathrm{hPT}+$ dicer siRNA $)$. 
role in favoring a pro-survival phenotype by differentially modulating ATF4 and CHOP protein levels.

\section{Elevated dicer protein levels observed during mild $\left(39.5^{\circ} \mathrm{C}\right)$ hyperthermia-induced thermotolerance is associated with a pro-survival outcome in HeLa and MEF cells}

A previous study in HeLa cells showing that heating HeLa cells at $40^{\circ} \mathrm{C}$ confers resistance to heat shock-induced apoptosis [8] prompted the question: do the elevated dicer protein levels, observed during mild $\left(39.5^{\circ} \mathrm{C}\right)$ hyperthermiainduced thermotolerance, influence caspase- 3 activation in cells challenged with a cytotoxic heat shock insult at $43^{\circ} \mathrm{C}$ ?

Mild $\left(39.5^{\circ} \mathrm{C}\right)$ hyperthermia alone, or in combination with control or dicer-targeting siRNAs, was not cytotoxic to HeLa cells, as evidenced by the lack of cleaved caspase- 3 in these experiments (Figure 8A, lanes 1-3; 6-8, and 1214). Similar results were observed in MEF cells (Figure $8 \mathrm{~A}$, lanes 16-18; 21-23 and 26-28).
Thermotolerant HeLa and MEF cells challenged with a heat shock insult showed consistently lower levels of cleaved caspase- 3 compared to cells that received the heat shock treatment alone (Figure 8A, lanes 4-5; $9-10 ; 19-20 ; 24-25$, and Figure 8B). These results are consistent with our initial observations suggesting that thermotolerant HeLa and MEF cells are better able to withstand a heat shock insult (see Figure 1E and 1F). Importantly, dicer knockdown in HeLa and MEF cells that were heated for $16 \mathrm{~h}$ at $39.5^{\circ} \mathrm{C}$ had significantly greater levels of cleaved caspase- 3 when challenged with a heat shock insult (Figure 8A, lanes 14-15; 2930 , and Figure $8 \mathrm{~B}$ ). Taken together, our data suggests that preventing mild $\left(39.5^{\circ} \mathrm{C}\right)$ hyperthermia-induced increases in dicer protein levels results in an increase in heat shock-induced cleaved caspase-3. This again supports the thesis that elevated dicer protein levels observed during mild $\left(39.5^{\circ} \mathrm{C}\right)$ hyperthermia-induced thermotolerance are associated with a pro-survival outcome.
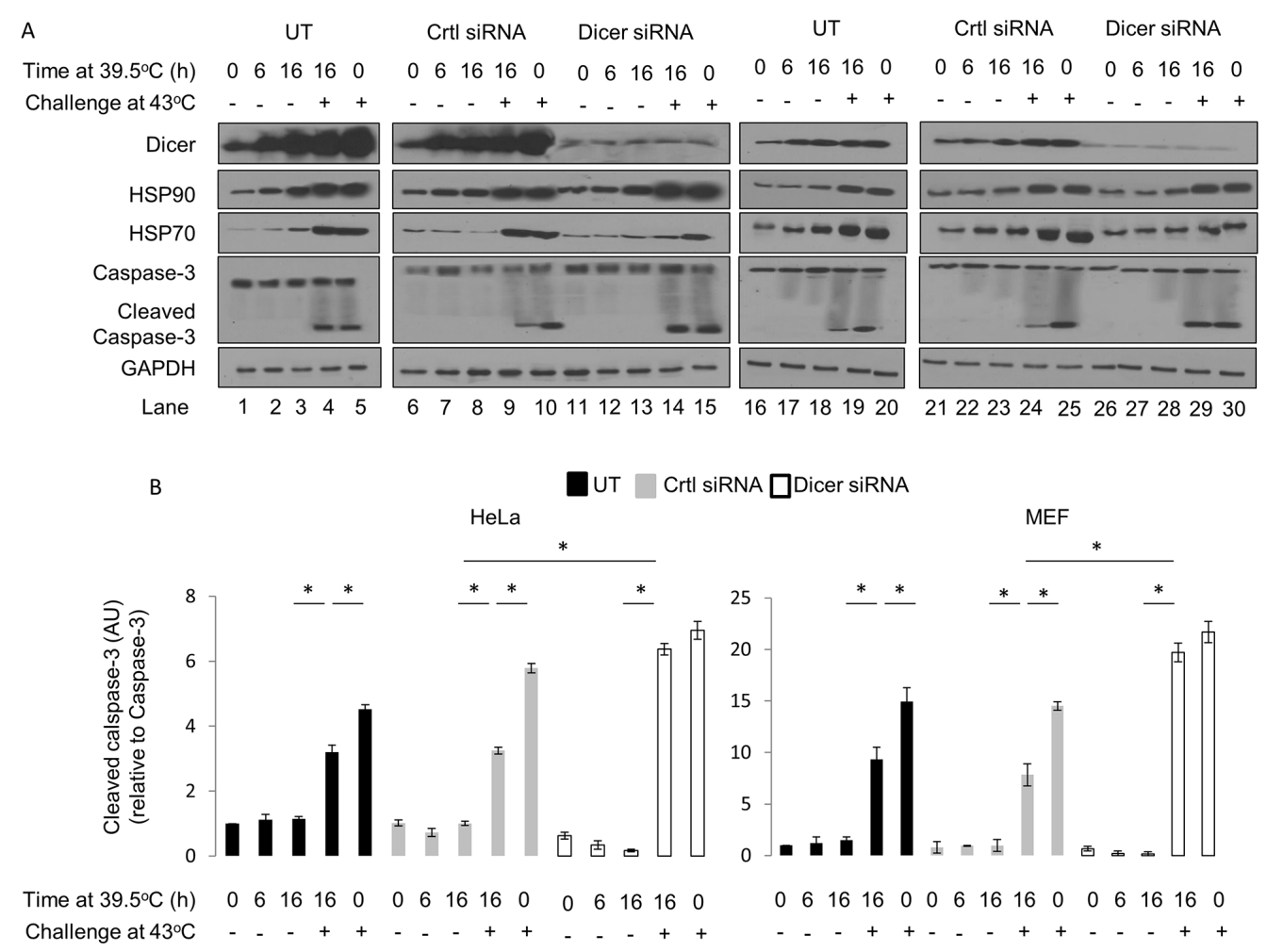

Figure 8: Elevated dicer protein levels observed during mild hyperthermia $\left(39.5^{\circ} \mathrm{C}\right)$ induced thermotolerance is associated with a pro-survival outcome in HeLa and MEF cells. (A) Western blot analysis of dicer, HSP90, HSP70, caspase-3 and cleaved caspase-3 protein levels in HeLa cells pretreated at $39.5^{\circ} \mathrm{C}$ for $0 \mathrm{~h}, 6 \mathrm{~h}$ and $16 \mathrm{~h}$ and subsequently challenged with a heat shock insult at $43^{\circ} \mathrm{C}$. Experiments were conducted under untransfected (UT: lanes 1-5), control-transfected (Ctrl siRNA: lanes 6-10), and dicer knockdown (dicer siRNA: lanes 11-15). Identical experiments were conducted in MEF cells (lanes 16-30). (B) Caspase-3 and cleaved caspase-3 band intensities in (A), lanes 1-15, were first normalized to GAPDH corresponding to Caspase-3 (not shown) and further normalized to the $0 \mathrm{~h}$ time point in the untransfected group. The ratios of cleaved caspase- 3 to total caspase-3 levels are graphed. Caspase-3 and cleaved caspase-3 band intensity analysis as described in (B) conducted with results in MEF cells shown in (A), lanes 16-30. The representative western blot images for GAPDH correspond to the western blot image for dicer this figure. Values shown are mean \pm SEM. $\mathrm{n}=3, * \mathrm{p}<0.05$. 


\section{DISCUSSION}

The nexus of this study is the association of mild hyperthermia-induced increases in dicer protein levels with a thermotolerant phenotype and a description of a potential mechanism by which dicer may play a cytoprotective role. We show a link between increased dicer protein levels and the phosphorylation of Protein Kinase R (PKR) and eukaryotic Initiation Factor $2 \alpha$ (eIF2 $\alpha$ ), as well as the transactivation and differential modulation of ATF4 and CHOP in favor of a pro-survival phenotype in thermotolerant cells. Furthermore, our work showing an inverse relationship between dicer and cleaved caspase-3 protein levels suggests that dicer may influence both ER and mitochondrial apoptotic pathways. Our results support the notion that the role of elevated dicer protein levels in mediating phosphorylation events might be unrelated to its role in microRNA processing, thereby uncovering a potentially novel mechanism by which dicer protein levels may engage the ER stress network in thermotolerant cells.

It is important to note that dicer knockdown in $\mathrm{HeLa}$ and MEF cells heated at $39.5^{\circ} \mathrm{C}$ for $6 \mathrm{~h}$ and $16 \mathrm{~h}$ did not significantly alter the induction of HSP70 protein levels. HSP70 is well known for its role in conferring a thermotolerant phenotype [28]. Gupta et al. demonstrated using chemical inducers of ER stress that HSP72, the inducible isoform of HSP70, synergizes with the IRE1 $\alpha$ arm of the ER stress pathway, resulting in a cytoprotective outcome [29]. Whether HSP70 is involved in the ER stress pathway in our experiments is currently unclear and warrants further investigation. A detailed study focusing on the potential role of dicer in the HSR pathway is yet to be reported. Our results showing increases in dicer as well as HSP70 protein levels in HeLa cells (Figure 1A and 1B; lanes 1-6) and MEF (Figure 1C and 1D; lanes 1-6) prompts the question whether dicer plays a role in increasing HSP70 levels. Our knockdown studies in HeLa (Figure 1A and 1B; lanes 7-9) and MEF (Figure $1 \mathrm{C}$ and 1D; lanes 7-9) cells suggest that increases in dicer protein levels are not likely a prerequisite for increases in HSP70 levels during mild hyperthermia stress. However, given that dicer knockdown cells still contain dicer, it was unclear whether dicer may be involved in regulating HSP70. As an initial step in determining the mechanism by which dicer may potentially stabilize HSP70 protein levels during hyperthermia stress, we asked whether dicer is required for hyperthermia-induced increases in HSP70 protein levels. To this end, we heated wildtype (WT) and dicer deficient (DCR $\left.{ }^{-/}\right)$HCT116 cells at mild hyperthermia for $16 \mathrm{~h}$ and found that HSP70 protein levels increase in WT and $\mathrm{DCR}^{-/}$cells (Figure 2), suggesting that HSP70 protein synthesis and regulation may occur independently of changes in dicer protein levels. While our study was limited to analyzing HSP70 protein levels, other studies show that hyperthermia stress in the heat shock range induces several HSP family members, namely HSPs 27, 32, 60, 72 and 110 [30-32]. The patterns of HSP induction during extended periods of mild hyperthermic stress, and the potential role of dicer in influencing HSPs is outside the purview of this report. Future studies aimed at investigating dicer's influence on the HSR could contribute to the establishment of a comprehensive working model for dicer in thermotolerant cells.

Interestingly, our results from PKR inhibitor studies suggest that PKR may play an intermediary role between dicer and eIF $2 \alpha$. Cawley et al., report that eIF $2 \alpha$ phosphorylation remains unaltered in dicer knockdown HCT116 cells treated with ER stress-inducing chemicals [33], suggesting that the ER stress pathway can be activated chemically via dicer-independent mechanisms. Our results however, suggest a causal link between elevated dicer protein levels and eIF $2 \alpha$ phosphorylation, potentially mediated by PKR. Hence, a question arises as to how dicer protein levels and the PKR-eIF2 $\alpha$ axis might be mechanistically linked in the context of mild hyperthermia stress. Although our data does not elucidate a definitive mechanism, we propose that the Protein Activator of PKR (PACT) - a dicer-interacting protein and a strong inducer of PKR activation [34], may be involved in the pathway linking elevated dicer protein levels and the PKR-eIF $2 \alpha$ axis during mild $\left(39.5^{\circ} \mathrm{C}\right)$ hyperthermia stress. Future work aimed at analyzing the effect of mild hyperthermia stress on the phosphorylation of various PACT serine residues (S18, S246, S287) and their biological outcomes will add to our understanding of the role of dicer in the ER stress pathway during experimentally induced thermotolerance.

Signal transduction is regulated, at least in part, via microRNAs. For example, a study by Sahasrabuddhe et al. shows that the genetic ablation of dicer leads to widespread deregulation in multiple pathways that are strongly dependent on phosphorylation events [35]. Other studies have shown that the eIF $2 \alpha$ kinase PKR is subject to regulation by miR-29b, and potentially other microRNAs [36, 37]. The conclusions drawn from our dicer LOF cell line studies are currently limited to one cell line. Future work utilizing genetic ablation approaches will likely clarify the role of dicer in thermotolerance. A study in fission yeast shows that DCR1 (a homologue of human DICER1) acts cooperatively with HSP104 to mitigate thermal stress-induced prion aggregation [38]. It is plausible that the role of human dicer in conferring cellular robustness during thermal stress could represent an evolutionary remnant from an era when thermal stress adaptation was closely linked to survival in harsh environments.

While our studies focused only on ATF4, there are additional factors that regulate $\mathrm{CHOP}$. These factors include ATF2 during leucine starvation; ATF3 during arsenite-induced stress and hypoxia; and ATF6 and XBP1 in cells exposed to chemical inducers of ER stress 
[39-41]. A leading study in the field proposes that all of the aforementioned transcription factors are required to achieve maximal induction of CHOP [42]. However, a comprehensive description of the various mechanisms through which $\mathrm{CHOP}$ is transcriptionally regulated during mild hyperthermia stress is currently lacking. Here we suggest that elevated dicer protein levels observed during mild $\left(39.5^{\circ} \mathrm{C}\right)$ hyperthermia-induced thermotolerance might be influencing the eIF2 $\alpha$-ATF4-CHOP axis and that future studies should include an analysis of the role of dicer in potentially regulating the other known transcriptional regulators of $\mathrm{CHOP}$ in thermotolerant cells.

Drawing a clear link between the protein levels of dicer and CHOP is limited by a technical incongruence: bands on the western blot in Figure 7 do not always correspond to the bar graphs in this instance. To address this issue, we have conducted experiments with technical replicates of samples used in experiments pertaining to Figure 7D and have analyzed CHOP protein levels in control $\left(37^{\circ} \mathrm{C}\right)$ and in dicer knockdown $(16 \mathrm{~h}$ pre-treated at $\left.39.5^{\circ} \mathrm{C}\right) \mathrm{MEF}$ cells exposed to heat shock at $43^{\circ} \mathrm{C}$ for $1 \mathrm{~h}$ (data not shown). Results from this confirmatory experiment suggest that while there were variations in CHOP protein levels between replicates, the overall outcome was largely consistent with the results shown in Figure 7F: CHOP protein levels in control $\left(37^{\circ} \mathrm{C}\right)$ cells exceed those in dicer knockdown (siRNA to dicer $+16 \mathrm{~h}$ pre-treated at $\left.39.5^{\circ} \mathrm{C}\right)$ cells under heat shock $\left(43^{\circ} \mathrm{C}\right)$ for $1 \mathrm{~h}$.

Although this work implicates a link between mild $\left(39.5^{\circ} \mathrm{C}\right)$ hyperthermia-induced increases in dicer protein levels and eIF $2 \alpha$ phosphorylation, a potential mechanistic limitation is that a link between dicer protein levels and ATF4 and CHOP remains unclear. To the best of our knowledge, there are no studies in HeLa and MEF cells suggesting that ATF4 can be induced independently of eIF2 $\alpha$ phosphorylation. Moreover, the robust nature of the eIF2 $\alpha$-ATF4-CHOP axis is exemplified by the observation that ATF4 and CHOP induction is abrogated in eIF $2 \alpha$ S51A cells [41]. On the basis of our results, we propose that dicer is upstream of the eIF2 $\alpha$-ATF4-CHOP axis. If this is the case, a question arises as to whether the ectopic overexpression of dicer would lead to the spontaneous induction of ATF4 and CHOP. To address this question, we overexpressed dicer in HeLa cells and found that neither ATF4 nor CHOP were induced (data not shown). Given that plasmid gene expression is dependent on active protein translation; and given that ATF4 and CHOP are induced upon translation inhibition, it is challenging to demonstrate a direct link between elevated dicer protein levels and ATF4 and CHOP. This work provides a rationale for future studies aimed at determining whether dicer may act as a signaling mediator within the ER stress network.

A study in MEFs using non-cytotoxic doses of the ER stress-inducing chemical tunicamycin showed that $\mathrm{CHOP}$ protein levels increase up to 8 -fold at $16 \mathrm{~h}$ after treatment initiation and gradually decline to near-baseline levels by 24h [43]. The Rutkowski study (43) proposes that CHOP non-responsiveness, or the lack of an increase in CHOP protein levels over time, leads to stress adaptation since the cellular abundance of CHOP is insufficient to trigger pro-apoptotic programs. Our results showing an initial increase (6h of heating) and a subsequent decline in CHOP protein levels during an extended period of heating (16h) supports the idea that cells might be adapting to ER stress during experimentally induced thermotolerance. In addition, the lack of an increase in ATF4 and CHOP protein levels in dicer knockdown HeLa and MEF cells supports the concept that elevated dicer protein levels might be playing a role in facilitating cellular stress adaptation mechanisms, potentially by modulating ATF 4 and CHOP protein levels.

Dicer protein levels increase with heat shock (Figure 8A; lanes 4, 5, 9, 10, 19, 20, 24 and 25). While a cytoprotective role for dicer has been suggested [23, 24, this report], one study also highlights a role for dicer in programmed cell death downstream of caspase-3 [45]. An important observation in this study was that elevated dicer protein levels observed during mild $\left(39.5^{\circ} \mathrm{C}\right)$ hyperthermia stress were associated with a pro-survival outcome. A limitation is that this cannot be extrapolated to interpret that the increases in dicer protein levels observed during the heat shock will continue to sustain pro-survival pathways. The role of dicer in heat shockinduced apoptosis is currently unknown and requires further exploration.

In conclusion, this work provides data that the thermotolerant phenotype is sustained, at least in part, by elevated dicer protein levels observed during mild $\left(39.5^{\circ} \mathrm{C}\right)$ hyperthermia-induced thermotolerance. Under these conditions, the elevated dicer protein level is linked to the phosphorylation of eIF $2 \alpha$ and the modulation of ATF4 and CHOP to favor a pro-survival outcome. Our study proposes a novel role for dicer in the cellular stress response to mild hyperthermia that is likely distinct from its role in microRNA processing.

\section{MATERIALS AND METHODS}

\section{Cell lines and culture conditions}

HeLa cells (CCL-2) were purchased from the American Type Culture Collection (ATCC) (Manassas, VA) and cultured according to ATCC's instructions. Wildtype and dicer loss-of-function (LOF) MEF cells were a generous gift from Dr. Gaspare La Rocca (Memorial Sloan Kettering) and were cultured in DMEM with $10 \%$ FBS, supplemented with $1 \%$ L-Glutamine. Both HeLa and murine embryonic fibroblast (MEF) cell culture media were supplemented with an antibiotic/antimycotic cocktail (ThermoFisher Scientific, Grand Island, NY). The $\mathrm{DCR}^{-/}$cells used in our studies were used as previously 
described [46]. Our results showing very low levels of a band corresponding to dicer are consistent with previous work by others $[47,48]$. WT and DCR ${ }^{-/}$HCT116 cells were grown in DMEM supplemented with $10 \% \mathrm{FBS}$, as described previously [47].

\section{Hyperthermia treatments}

For mild hyperthermia treatments, cell cultures were incubated in water-jacketed incubators $(7 \% \mathrm{CO} 2$ for $\mathrm{HeLa} ; 5 \%$ for $\mathrm{MEF}$ ) at $39.5^{\circ} \mathrm{C}$ for the indicated times. For heat shock treatments, cell cultures were incubated in temperature-controlled water baths at $43^{\circ} \mathrm{C}$ for the indicated times. Heat shocked cells were transferred to water-jacketed incubators at $37^{\circ} \mathrm{C}$ for $6 \mathrm{~h}$ following heat shock in experiments that involved the visualization of cleaved caspase-3. A study on heat shock-induced caspase activation suggests that a recovery period of at least $3 \mathrm{~h}$ at $37^{\circ} \mathrm{C}$ is necessary to visualize caspase activation [44]. Our preliminary experiments analyzing cleaved caspase- 3 suggest that a recovery period of $5-6 \mathrm{~h}$ at $37^{\circ} \mathrm{C}$ is optimal in our experimental system (data not shown). Cells were harvested to obtain total protein at the experimental endpoint.

\section{MTT cell viability assay}

Cells were first plated at 10,000 cells per well in 24-well plates and subsequently treated with mild hyperthermia or heat shock, as per the experimental requirements. MTT reagent [3-(4,5-dimethylthiazol-2yl)-2,5-diphenyltetrazoliumbromide] (Sigma-Aldrich, St. Louis, MO) was added at $1 \mathrm{X}$ concentration. Following $4 \mathrm{~h}$ incubation at $37^{\circ} \mathrm{C}$, the media containing MTT reagent was replaced with isopropanol $(600 \mathrm{uL} /$ well). Following 20 min incubation at $37^{\circ} \mathrm{C}$ to dissolve the formazan crystals, $200 \mathrm{uL}$ of final reaction product was transferred to different wells of a 96 well plate and the absorbance was measured at $570 \mathrm{~nm}$.

\section{Protein isolation}

Total protein isolation was performed as previously described [25]. Briefly, cell pellets were lysed with RIPA lysis buffer (Sigma, St Louis, MO) supplemented with a protease inhibitor cocktail (Sigma), HALT phosphatase inhibitor (Pierce, Rockford, IL), and 1mM DTT. Protein lysates were incubated for $30 \mathrm{~min}$ on ice and subsequently centrifuged at $10,000 \mathrm{Xg}$. The supernatants were collected and stored at $-80^{\circ} \mathrm{C}$.

\section{Western blotting}

Western blotting was performed as previously

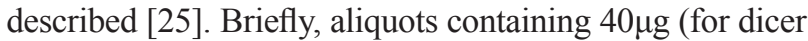
western blots from cell lysates derived from HeLa cells), $20 \mu \mathrm{g}$ (for dicer western blots from cell lysates derived from MEF cells, and $20 \mu \mathrm{g}$ (all other proteins) of total protein were prepared. Samples were then supplemented with SDS buffer and 0.13M DTT (Sigma) and run on 7\% (for dicer) or $10 \%$ (for all other proteins) SDS polyacrylamide gels. The kaleidoscope molecular weight ladder $(250-25 \mathrm{kDa})$ from BioRad was used in all western blots. Samples were then transferred to PVDF membranes (BioRad) and blocked with $5 \%$ milk in TTBS (Tween 20 Tris-Buffered Saline). Samples were blocked with 5\% BSA in TTBS for the analysis of phosphorylated proteins. Subsequently, PVDF membranes were probed with the appropriate primary and secondary antibodies, developed with West Pico Chemiluminescent substrate (Pierce), and analyzed on X-ray film (Thermo Scientific, Waltham, MA). For experiments involving the simultaneous analysis of multiple proteins, PVDF membranes were cut to include sections containing proteins of the appropriate molecular weight prior to antibody incubation. For experiments involving the detection of phosphorylated proteins, the phosphorylated form of the protein was first detected by the method described above. Subsequently, the PVDF membrane was stripped with $0.1 \mathrm{~N}$ sodium hydroxide, neutralized and re-probed with the appropriate primary antibody to detect all forms of the same protein. Western blots were quantified by scanning $\mathrm{X}$-ray films. Protein band intensities were analyzed using the Image $\mathbf{J}$ image processing and analysis tool available at http://rsbweb.nih.gov/ij/. GAPDH served as the loading control for all proteins analyzed, unless indicated. Band intensities were normalized to the loading control within each biological replicate. The representative GAPDH gel images shown in each figure corresponds to the dicer gel image in the figure.

\section{Dicer activity assay}

A pre-miR-124a template was first generated via PCR using HeLa cell genomic DNA. The primers used to generate this template were designed using the miR-124a sequence made publically available through miRBase (mirbase.org). A T7 recognition element was included in one of the primers to facilitate in vitro transcription in a subsequent step. Pre-miR-124a was chosen for this assay because it is not endogenously produced in the cell types used in this study. The premiR-124a template was transcribed in vitro using the MegaScript $\mathrm{T} 7$ in vitro transcription kit (Ambion, Foster City, CA), together with $\alpha^{32}$ P-UTP (Perkin Elmer, Waltham, MA) to generate a $\alpha^{32} \mathrm{P}-\mathrm{UTP}$ radiolabeled pre-miR-124a. This radiolabeled pre-miR-124a was used in all of the activity assays. Protein lysates from $\mathrm{HeLa}$ cells grown at $37^{\circ} \mathrm{C}$ or at $39.5^{\circ} \mathrm{C}$, and protein lysates from wildtype and dicer LOF MEFs at $37^{\circ} \mathrm{C}$ were subsequently incubated for 16 hours with the radiolabeled pre-miR-124a. Once the reactions were complete, the samples were run on a denaturing Urea PAGE gel and specific mature-miR-124a cleavage products were quantified by exposure to a phosphorimaging cassette (Molecular Dynamics Storm). 


\section{siRNA transfection}

Control and dicer siRNAs targeting DICER1 in Homo sapiens and Mus musculus were purchased from Qiagen (Valencia, CA). SiRNA transfections were performed in accordance with the Jet Prime siRNA and plasmid DNA transfection kit protocol (VWR International, Radnor, PA). Transfections were carried out at $80 \mathrm{nM}$ for both dicer and control siRNAs. Total protein was isolated at $48 \mathrm{~h}$ and $72 \mathrm{~h}$ post-transfection for the analysis of dicer knockdown via western blotting.

\section{Antibodies}

Primary antibodies: Dicer (human), ATF4, CHOP, Caspase-3, total and phosphorylated eIF2 $\alpha$ (Ser51), total and phosphorylated PKR (Thr451) (Cell Signaling Technology, Boston, MA); Dicer (mouse) (Bethyl laboratories, Montgomery, TX); GAPDH, HSP90, HSP70 (Abcam, Cambridge, MA). Secondary antibodies: Antimouse IgG HRP conjugate and anti-rabbit IgG HRP conjugates (Promega, Madison, WI).

\section{Reagents}

PKR inhibitor [8-imidazol-4-ylmethylene-6Hazolidino 5,4-g benzothiazol-7-one (Calbiochem-EMD Millipore, Billerica, MA)] was used at a concentration of $250 \mathrm{nM}$ for validation experiments and with hyperthermia treatments. RNase inhibitor (Protector RNase inhibitor, Roche Life Sciences) was used (1.0 unit per reaction) in dicer activity assays.

\section{Statistical analysis}

The Student's t test function in SPSS 22.0.0.0 was used to determine statistical significance and $\mathrm{p}<0.05$ was considered statistically significant. Values shown are mean \pm SEM.

\section{Abbreviations}

ATF: activating transcription factor; ATF6f: activating transcription factor 6 (cleaved); ASK1: apoptosis signal-regulated kinase 1; BIP: binding immunoglobulin protein; BCL-2: B-cell lymphoma 2; BCL-XL: B-cell lymphoma XL; CHOP: C/EBP homologous protein; CYPB: cyclophilin B; ER: endoplasmic reticulum; ERAD: ER associated degradation; eIF $2 \alpha$ : eukaryotic initiation factor 2 alpha subunit; ERP72: ER protein $72 \mathrm{kDa}$; GAPDH: glyceraldehyde 3-phosphate dehydrogenase; GCN2: general control non-derepressible 2; GRP78: glucose regulated protein $78 \mathrm{kDa}$; HSF1: heat shock factor 1; HSP70: heat shock protein 70kDa; HSP90: heat shock protein $90 \mathrm{kDa}$; HRI: heme regulated interferon; IRE1 $\alpha$ : inositol requiring enzyme $1 \alpha$; JNK: jun $\mathrm{N}$-terminal kinase; miR: microRNA;
MEF: murine embryonic fibroblast; PERK: PKR-like endoplasmic reticulum kinase; PKR: protein kinase R; TNF: tumor necrosis factor; XBP1: X-box binding protein 1; XBP1s: X-box binding protein 1s.

\section{ACKNOWLEDGMENTS}

This work was supported by the NIH National Cancer Institute grant RO1 CA124971 and by M\&T Bank. The study also used shared resources supported by RPCI's Cancer Center Support Grant from the NCI P30 CA016056. The authors acknowledge Drs. Schneider and Magner for their suggestions and critiquing the manuscript and Ms. Jennifer Weisen for technical advice and training. We thank Dr. Elizabeth Repasky for insightful discussions and constructive comments of the manuscript.

\section{CONFLICTS OF INTEREST}

The author(s) declare no potential conflicts of interest.

\section{REFERENCES}

1. Kampinga HH. Cell biological effects of hyperthermia alone or combined with radiation or drugs: a short introduction to newcomers in the field. Int J Hyperthermia. 2006; 22: 191-196.

2. Horowitz M. Heat acclimation and cross-tolerance against novel stressors: genomic-physiological linkage. Prog Brain Res. 2007; 162: 373-392.

3. Xu X, Gupta S, Hu W, McGrath BC, Cavener DR. Hyperthermia induces the ER stress pathway. PloS One. 2011; 6: e23740.

4. Richter K, Haslbeck M, Buchner J. The heat shock response: life on the verge of death. Mol Cell. 2010; 40: 253-266.

5. Field SB, Anderson RL. Thermotolerance: a review of observations and possible mechanisms. Natl Cancer Inst Monogr. 1982; 61: 193-201.

6. Li JJ, Dewey WC. Relationship between thermal tolerance and protein degradation in temperature-sensitive mouse cells. J Cell Physiol. 1992; 151: 310-317.

7. Bettaieb A, Averill-Bates DA. Thermotolerance induced at a mild temperature of 40 degrees $C$ protects cells against heat shock-induced apoptosis. J Cell Physiol. 2005; 205: 47-57.

8. Glory A, Bettaieb A, Averill-Bates DA. Mild thermotolerance induced at 40 degrees $C$ protects cells against hyperthermiainduced pro-apoptotic changes in Bcl-2 family proteins. Int $\mathrm{J}$ Hyperthermia. 2014; 30: 502-512.

9. Henle KJ, Dethlefsen LA. Heat fractionation and thermotolerance: a review. Cancer Res. 1978; 38: 1843-1851. 
10. Urano M. Kinetics of thermotolerance in normal and tumor tissues: a review. Cancer Res. 1986; 46: 474-482.

11. Lepock JR. How do cells respond to their thermal environment? Int J Hyperthermia. 2005; 21: 681-687.

12. Bettaieb A, Averill-Bates DA. Thermotolerance induced at a mild temperature of 40 degrees $C$ alleviates heat shockinduced ER stress and apoptosis in HeLa cells. Biochim Biophys Acta. 2015; 1853: 52-62.

13. Chakrabarti A, Chen AW, Varner JD. A review of the mammalian unfolded protein response. Biotechnol Bioeng. 2011; 108: 2777-2793

14. Jansen G, Maattanen P, Denisov AY, Scarffe L, Schade B, Balghi H, Dejgaard K, Chen LY, Muller WJ, Gehring K, Thomas DY. An interaction map of endoplasmic reticulum chaperones and foldases. Mol Cell Proteomics. 2012; 11: 710-723.

15. Harding HP, Zhang Y, Ron D. Protein translation and folding are coupled by an endoplasmic-reticulum-resident kinase. Nature. 1999; 397: 271-274.

16. McAllister CS, Taghavi N, Samuel CE. Protein kinase PKR amplification of interferon beta induction occurs through initiation factor eIF-2alpha-mediated translational control. J Biol Chem. 2012; 287: 36384-36392.

17. Lu PD, Harding HP, Ron D. Translation reinitiation at alternative open reading frames regulates gene expression in an integrated stress response. J Cell Biol. 2004; 167: 27-33.

18. Fawcett TW, Martindale JL, Guyton KZ, Hai T, Holbrook NJ. Complexes containing activating transcription factor (ATF)/cAMP-responsive-element-binding protein (CREB) interact with the CCAAT/enhancer-binding protein $(\mathrm{C} /$ EBP)-ATF composite site to regulate Gadd153 expression during the stress response. Biochem J. 1999; 339: 135-141.

19. Nakagawa T, Zhu H, Morishima N, Li E, Xu J, Yankner BA, Yuan J. Caspase-12 mediates endoplasmic-reticulumspecific apoptosis and cytotoxicity by amyloid-beta. Nature. 2000; 403: 98-103.

20. Shore GC, Papa FR, Oakes SA. Signaling cell death from the endoplasmic reticulum stress response. Curr Opin Cell Biol. 2011; 23: 143-149.

21. McCullough KD, Martindale JL, Klotz LO, Aw TY, Holbrook NJ. Gadd153 sensitizes cells to endoplasmic reticulum stress by down-regulating $\mathrm{Bcl} 2$ and perturbing the cellular redox state. Mol Cell Biol. 2001; 21: 1249-1259.

22. Sano R, Reed JC. ER stress-induced cell death mechanisms. Biochim Biophys Acta. 2013; 1833: 3460-3470.

23. Ho JJ, Metcalf JL, Yan MS, Turgeon PJ, Wang JJ, Chalsev M, Petruzziello-Pellegrini TN, Tsui AK, He JZ, Dhamko H, Man HS, Robb GB, Teh BT, et al. Functional importance of Dicer protein in the adaptive cellular response to hypoxia. J Biol Chem. 2012; 287: 29003-29020.

24. Asada S, Takahashi T, Isodono K, Adachi A, Imoto H, Ogata T, Ueyama T, Matsubara H, Oh H. Downregulation of Dicer expression by serum withdrawal sensitizes human endothelial cells to apoptosis. Amer J Physiol Heart Circul Physiol. 2008; 295: H2512-H2521.

25. Oshlag JZ, Devasthanam AS, Tomasi TB. Mild hyperthermia enhances the expression and induces oscillations in the Dicer protein. Int J Hyperthermia. 2013; 29: 51-61.

26. Scheuner D, Patel R, Wang F, Lee K, Kumar K, Wu J, Nilsson A, Karin M, Kaufman RJ. Double-stranded RNAdependent protein kinase phosphorylation of the alphasubunit of eukaryotic translation initiation factor 2 mediates apoptosis. J Biol Chem. 2006; 281: 21458-21468.

27. Wek RC, Jiang HY, Anthony TG. Coping with stress: eIF2 kinases and translational control. Biochem Soc Trans. 2006; 34: 7-11.

28. King YT, Lin CS, Lin JH, Lee WC. Whole-body hyperthermia-induced thermotolerance is associated with the induction of heat shock protein 70 in mice. J Exp Biol. 2002; 205: 273-278.

29. Gupta S, Deepti A, Deegan S, Lisbona F, Hetz C, Samali A. HSP72 protects cells from ER stress-induced apoptosis via enhancement of IRE1alpha-XBP1 signaling through a physical interaction. PLoS Biol. 2010; 8: e1000410.

30. Wissing D, Jaattela M. HSP27 and HSP70 increase the survival of WEHI-S cells exposed to hyperthermia. Int $\mathrm{J}$ Hyperthermia. 1996; 12: 125-138.

31. Bechtold DA, Brown IR. Induction of Hsp27 and Hsp32 stress proteins and vimentin in glial cells of the rat hippocampus following hyperthermia. Neurochem Res. 2003; 28: 1163-1173.

32. Torrente MP, Shorter J. The metazoan protein disaggregase and amyloid depolymerase system: Hsp110, Hsp70, Hsp40, and small heat shock proteins. Prion. 2013; 7: 457-463.

33. Cawley K, Logue SE, Gorman AM, Zeng Q, Patterson J, Gupta S, Samali A. Disruption of microRNA biogenesis confers resistance to ER stress-induced cell death upstream of the mitochondrion. PloS One. 2013; 8: e73870.

34. Patel CV, Handy I, Goldsmith T, Patel RC. PACT, a stressmodulated cellular activator of interferon-induced doublestranded RNA-activated protein kinase, PKR. J Biol Chem. 2000; 275: 37993-37998.

35. Sahasrabuddhe NA, Huang TC, Kumar P, Yang Y, Ghosh B, Leach SD, Chaerkady R, Pandey A. Ablation of Dicer leads to widespread perturbation of signaling pathways. Biochem Biophys Res Commun. 2015; 463: 389-394.

36. Silva VA, Polesskaya A, Sousa TA, Correa VM, Andre ND, Reis RI, Kettelhut IC, Harel-Bellan A, De Lucca FL. Expression and cellular localization of microRNA-29b and RAX, an activator of the RNA-dependent protein kinase (PKR), in the retina of streptozotocin-induced diabetic rats. Mol Vision. 2011; 17: 2228-2240.

37. Qi Y, Zhang M, Li H, Frank JA, Dai L, Liu H, Chen G. MicroRNA-29b regulates ethanol-induced neuronal apoptosis in the developing cerebellum through SP1/RAX/ PKR cascade. J Biol Chem. 2014; 289: 10201-10210. 
38. Oberti D, Biasini A, Kirschmann MA, Genoud C, Stunnenberg R, Shimada Y, Buhler M. Dicer and Hsp104 function in a negative feedback loop to confer robustness to environmental stress. Cell Rep. 2015; 10: 47-61.

39. Bruhat A, Jousse C, Carraro V, Reimold AM, Ferrara M, Fafournoux P. Amino acids control mammalian gene transcription: activating transcription factor 2 is essential for the amino acid responsiveness of the CHOP promoter. Mol Cell Biol. 2000; 20: 7192-7204.

40. Chen BP, Wolfgang CD, Hai T. Analysis of ATF3, a transcription factor induced by physiological stresses and modulated by gadd153/Chop10. Mol Cell Biol. 1996; 16: 1157-1168.

41. Harding HP, Novoa I, Zhang Y, Zeng H, Wek R, Schapira M, Ron D. Regulated translation initiation controls stressinduced gene expression in mammalian cells. Mol Cell. 2000; 6: 1099-1108.

42. Oyadomari S, Mori M. Roles of CHOP/GADD153 in endoplasmic reticulum stress. Cell Death Differ. 2004; 11: 381-389.

43. Rutkowski DT, Arnold SM, Miller CN, Wu J, Li J, Gunnison KM, Mori K, Sadighi Akha AA, Raden D, Kaufman RJ. Adaptation to ER stress is mediated by differential stabilities of pro-survival and pro-apoptotic mRNAs and proteins. PLoS Biol. 2006; 4: e374.

44. Moulin M, Arrigo AP. Caspases activation in hyperthermiainduced stimulation of TRAIL apoptosis. Cell Stress Chaperones. 2008; 13: 313-326.
45. Nakagawa A, Shi Y, Kage-Nakadai E, Mitani S, Xue D. Caspase-dependent conversion of Dicer ribonuclease into a death-promoting deoxyribonuclease. Science. 2010; 328: 327-334.

46. Cummins JM, He Y, Leary RJ, Pagliarini R, Diaz LA Jr, Sjoblom T, Barad O, Bentwich Z, Szafranska AE, Labourier E, Raymond CK, Roberts BS, Juhl H, et al. The colorectal microRNAome. Proc Natl Acad Sci U S A. 2006; 103: 3687-3692.

47. Yu Z, Wang L, Wang C, Ju X, Wang M, Chen K, Loro E, Li Z, Zhang Y, Wu K, Casimiro MC, Gormley M, Ertel A, et al. Cyclin D1 induction of Dicer governs microRNA processing and expression in breast cancer. Nat Commun. 2013; 4: 2812.

48. Asada K, Canestrari E, Fu X, Li Z, Makowski E, Wu YC, Mito JK, Kirsch DG, Baraban J, Paroo Z. Rescuing dicer defects via inhibition of an anti-dicing nuclease. Cell Rep. 2014; 9: 1471-1481.

49. Baird TD, Wek RC. Eukaryotic initiation factor 2 phosphorylation and translational control in metabolism. Adv Nutr. 2012; 3: 307-321.

50. Rao RV, Hermel E, Castro-Obregon S, del Rio G, Ellerby LM, Ellerby HM, Bredesen DE. Coupling endoplasmic reticulum stress to the cell death program. Mechanism of caspase activation. J Biol Chem. 2001; 276: 33869-33874.

51. Quick QA, Faison MO. CHOP and caspase 3 induction underlie glioblastoma cell death in response to endoplasmic reticulum stress. Exp Ther Med. 2012; 3: 487-492. 